Gazetteer of Hydrologic Characteristics of Streams in Massachusetts--Coastal River Basins of the South Shore and Buzzards Bay

$$
-481.09 .-1
$$

\author{
U.S. GEOLOGICAL SURVEY \\ Water-Resources Investigations Report 84-4288
}

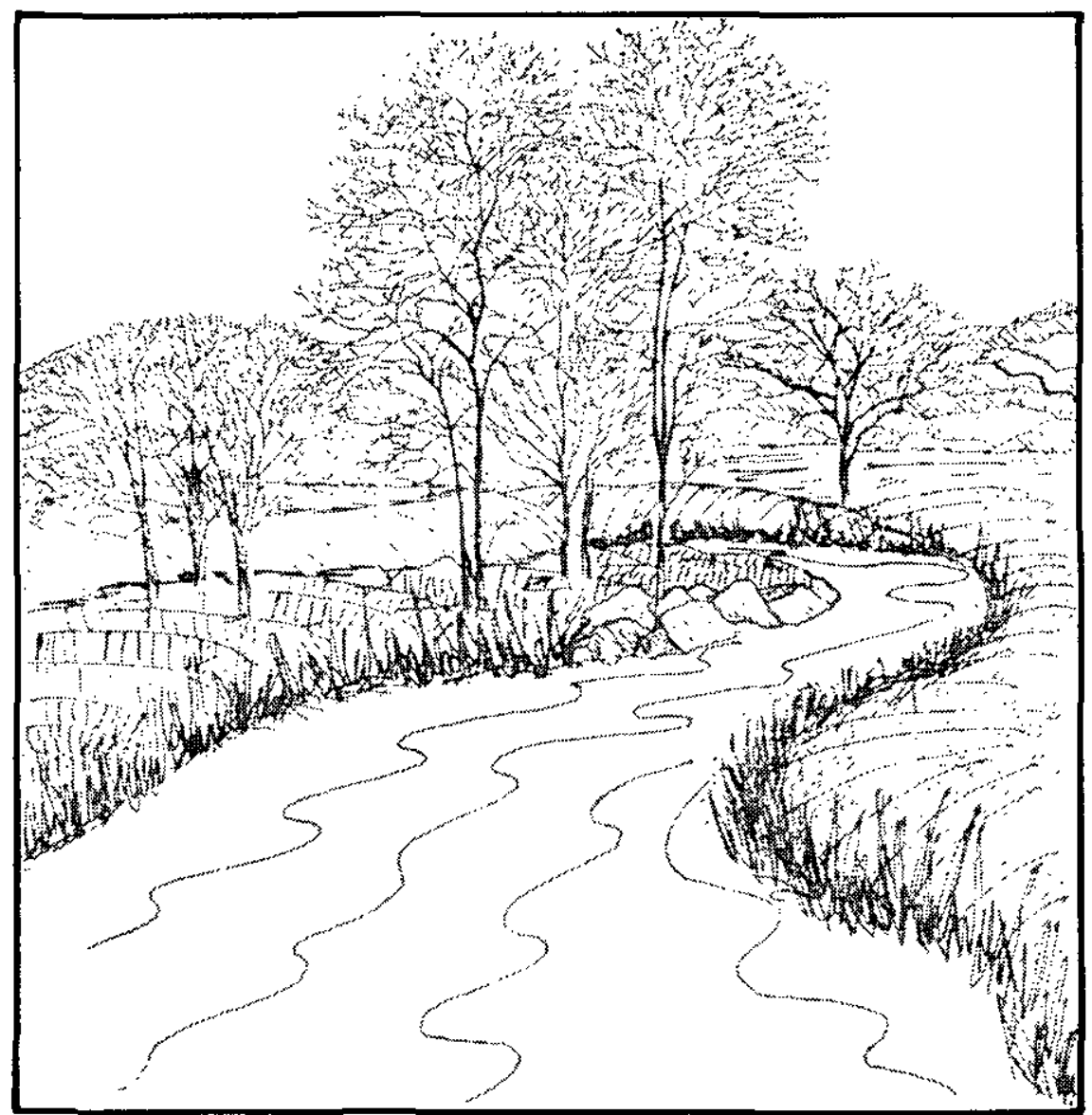

Prepared in cooperation with the

COMMONWEALTH OF MASSACHUSETTS

DEPARTMENT OF ENVIRONMENTAL QUALITY ENGINEERING DIVISION OF WATER POLLUTION CONTROL 


\title{
GAZETTEER OF HYDROLOGIC CHARACTERISTICS OF STREAMS IN MASSACHUSETTS--COASTAL RIVER BASINS OF THE SOUTH SHORE AND BUZZARDS BAY
}

By S. William Wandle, Jr., and Mary A. Morgan

U.S. GEOLOGICAL SURVEY

Water-Resources Investigations Report 84-4288

\begin{abstract}
Prepared in cooperation with the
COMMONWEALTH OF MASSACHUSETTS

DEPARTMENT OF ENVIRONMENTAL QUALITY ENGINEERING

DIVISION OF WATER POLLUTION CONTROL
\end{abstract}

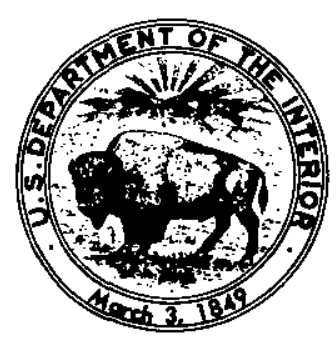

Boston, Massachusetts

1984 


\section{UNITED STATES DEPARTMENT OF THE INTERIOR \\ WILLIAM P. CLARK, Secretary \\ GEOLOGICAL SURVEY \\ Dallas L. Peck, Director}

For additional information write to:

U.S. Geological Survey

150 Causeway Street, Suite 1309

Boston, MA 02114
Copies of this report can be purchased from:

Open-File Services Section Western Distribution Branch

U.S. Geological Survey

Box 25425, Federal Center

Denver, CO 80225

Telephone: (303) 236-7476 
Page

Introduction -

Hydrologic data -

Basin characteristics-...

Streamflow characteristics

Streamflow analysis--

Streamflow data base - 11

Daily flow statistics -

Low-flow statistics - 12

Summary

Selected references

\section{ILLUSTRATIONS}

Figure 1. Map showing location of the coastal river basins of the South Shore and Buzzards Bay-ne 3

2-3. Map showing location of the gaging stations and low-flow partial-record stations and miscellaneous sites in the coastal river basins of:

2. the South Shore

3. Buzzards Bay - 6

4-6. Graphs showing:

4. monthly discharges and extremes for the Indian Head River

at Hanover, Mass. (site 6), during 1967-82- 9

5. flow-duration curve for the Indian Head River at

Hanover, Mass. (site 6), during 1967-82 - 10

6. low-flow frequency curve for the Indian Head River at

Hanover, Mass. (site 6), during 1968-82

\section{TABLES}

Table 1. Stream-order listing, selected drainage areas, and locations of Page subbasins in the coastal river basins of the South Shore and Buzzards Bay

2. Summary of daily flow records available in the coastal river basins of the South Shore and Buzzards Bay

3. Basin characteristics for selected stream-gaging stations in the coastal river basins of the South Shore and Buzzards Bay

4. Streamflow characteristics at selected stream-gaging stations

5. Summary of 7-day low-flow characteristics, drainage area, and period of record for low-flow partial-record stations and miscellaneous sites 


\section{CONVERSION FACTORS}

The following factors may be used to convert the inch-pound units published herein to the International System of Units (SI).

Multiply inch-pound units

inch (in)
foot (ft)
mile ( $\mathrm{mi})$
square mile $\left(\mathrm{mi}^{2}\right)$
cubic foot per second (ft $\left.{ }^{3} / \mathrm{s}\right)$
cubic foot $\mathrm{per}$ second $\mathrm{per}$ square
mile $\left[\left(\mathrm{ft}^{3} / \mathrm{s}\right) / \mathrm{mi}^{2}\right]$

foot per mile $(\mathrm{ft} / \mathrm{mi})$
By

To obtain SI Units

\section{Length}

$\begin{array}{ll}25.4 * & \text { millimeter }(\mathrm{mm}) \\ 0.3048 & \text { meter }(\mathrm{m}) \\ 1.609 & \text { kilometer }(\mathrm{km}) \\ \text { Area } & \end{array}$

2.590

square kilometer $\left(\mathrm{km}^{2}\right)$

\section{Flow}
0.02832 cubic meter per second $\left(\mathrm{m}^{3} / \mathrm{s}\right)$
cubic meter per second per square
$0.01093 \quad$ kilometer $\left[\left(\mathrm{m}^{3} / \mathrm{s}\right) / \mathrm{km}^{2}\right]$

Slope
0.1894
meter per kilometer $(\mathrm{m} / \mathrm{km})$

\section{Temperature}

Temperature in degrees Fahrenheit $\left({ }^{\circ} \mathrm{F}\right)$ can be converted to degrees Celsius $\left({ }^{\circ} \mathrm{C}\right)$ as follows:

$$
{ }^{\circ} \mathrm{C}=5 / 9\left({ }^{\circ} \mathrm{F}-32\right) \text {. }
$$

*Exact. 


\title{
GAZETTEER OF HYDROLOGIC CHARACTERISTICS OF STREAMS \\ IN MASSACHUSETTS-COASTAL RIVER BASINS OF
}

THE SOUTH SHORE AND BUZZARDS BAY

-By S. William Wandle, Jr., and Mary A. Morgan

\begin{abstract}
The coastal river basins include the minor river basins draining into Massachusetts Bay along the South Shore or into Buzzards Bay. The larger of these basins are the North, South, Jones, Wareham, Weweantic, Mattapoisett, Acushnet, and Slocums River basins. Drainage areas, using the latest available 1:24,000 scale topographic maps, were computed for the first time for ungaged streams draining more than 3 square miles and were re-computed for datacollection sites.

Statistics on streamflow characteristics computed with a new data base are presented for six gaged streams. Daily flow records through 1982 were used to compute annual and monthly flow statistics, duration of daily flow values, and the annual 7-day mean low flow at the 2-year and 10-year recurrence intervals. Seven-day low-flow statistics are presented for 49 partialrecord sites, and the procedures used to determine the hydrologic characteristics of the basin are summarized. This gazetteer will aid in the planning and siting of water-resources related activities and will provide a common data base for governmental agencies and the engineering and planning communities.
\end{abstract}

\section{INTRODUCTION}

Information on hydrologic characteristics, including drainage areas, frequency of low flows, and duration of daily flows, is necessary to plan and manage water-resources related activities. Governmental agencies and the engineering and planning community need streamflow characteristics to satisfy requirements relative to fisheries management, hydropower, land-use planning, stream-systems analysis, waste assimilation, and water-resources development and management. No current hydrologic data base containing a comprehensive list of drainage areas, monthly flows, low-flow frequencies, and duration of daily flows is available for most of the Massachusetts stream systems. Drainage areas are available for selected sites where streamflow data are collected. Streamflow characteristics are presented in various reports, but these data, to be current, need to be re-analyzed using the latest available daily flow records. 
In response to this need, a study was begun in 1980, in cooperation with the Massachusetts Division of Water Pollution Control, to analyze available streamflow and river-basin characteristics, and to compute subbasin drainage areas. This report is part of a series of gazetteers on the hydrologic characteristics of the major river basins in the State. Gazetteers are also available for the coastal river basins of the North Shore and Massachusetts Bay (Wandle, 1984a), Connecticut River basin (Wandle, 1984b), Hudson River basin (Wandle, 1984c), Merrimack River basin (Wandle and Fontaine, 1984), Taunton and Ten Mile River basins (Wandle and Keezer, 1984), Thames River basin (Wandle and LeBlanc, 1984), Housatonic River basin (Wandle and Lippert, 1984), Blackstone River basin (Wandle and Phipps, 1984). This report provides the first detailed listing of drainage areas and streamflow characteristics derived from daily flow records in the coastal drainage basins of the South Shore and Buzzards Bay. These streamflow characteristics are an expansion and an update of those given in Williams and Tasker (1974a, 1974b). Low-flow estimates are compiled for the low-flow sites in Williams and Tasker (1974a, $1974 \mathrm{~b}, 1978)$ except for the Mattapoisett River sites where the values are from Olimpio and de Lima (1984).

The coastal river basins in southeastern Massachusetts (fig. 1 ) include the several minor river basins draining into Massachusetts Bay or Buzzards Bay. The North, South, Jones, Wareham, Weweantic, Mattapoisett, Acushnet, and Slocums River basins are the larger of these basins. All or part of the following communities are included in the study area: Abington, Acushnet, Bourne, Carver, Cohasset, Dartmouth, Duxbury, Fairhaven, Freetown, Halifax, Hanover, Hanson, Hingham, Kingston, Lakeville, Marion, Marshfield, Mattapoisett, Middleborough, New Bedford, Norwell, Pembroke, Plymouth, Plympton, Rochester, Rockland, Sandwich, Scituate, Wareham, Westport, Weymouth, and Whitman.

Streamflow characteristics presented for the six continuously gaged streams are based upon a new sample of daily flow records in comparison to flow records used in Higgins (1967), Knox and Soule (1949), Male and Ogawa (1982), and Williams and Tasker (1974a, 1974b). Streamflow records through the 1982 water year were available for this analysis. For each site, records were selected to represent a flow regime influenced by fairly constant river basin conditions (Wandle, 1983).

Drainage areas were re-computed for data-collection sites and computed for the first time for ungaged streams draining greater than $3 \mathrm{mi}^{2}$. Drainage divides, as delineated on the latest available 1:24,000 scale topographic quadrangle maps (Brackley and Wandle, 1983); (Wandle and Frimpter, 1982), were used to calculate drainage areas. Drainage areas, for the gaging stations, in earlier reports were computed using the drainage divides as outlined on $1: 31,680$ or $1: 24,000$ scale topographic quadrangle maps.

Streamflow data used in this study are a part of the historic streamflow data collected under agreements with State and Federal agencies and the U.S. Geological Survey. Most of the low-flow discharge measurements used in determining low-flow estimates at partial-record sites were collected during the water-resources investigations of the coastal drainage basins of southeastern Massachusetts (Williams and Tasker, 1974a, 1974b, 1978). The array of basin characteristics was created during an evaluation of available streamflow data in central New England (Johnson, 1970). This file is an expansion of the characteristics abstracted by Langbein and others (1947), and by Benson (1962). Basin characteristics were updated and additional characteristics were entered as part of a study to define floodflow characteristics of small streams (Johnson and Tasker, 1974, and Wandle, 1982). The hierarchical stream list was compiled by the Massachusetts Divisions of Water Pollution Control and Fisheries and Wildlife (Halliwell and others, 1982).

Data tabulated include drainage areas, basin and streamflow characteristics for gaging stations, including annual and monthly flow statistics, duration of daily flow values, and the annual 7-day mean low flow at the 2-year and 10-year recurrence intervals. Seven-day lowflow statistics for partial-record sites are also presented. An explanation of the procedures to determine the streamflow and basin characteristics is provided.

The authors thank the many persons who have kindly given time, information, and guidance during this study. Particular thanks are given to persons in the Geological Survey who assisted in the data collection, in the computation of the drainage areas, and in the preparation of this report. 


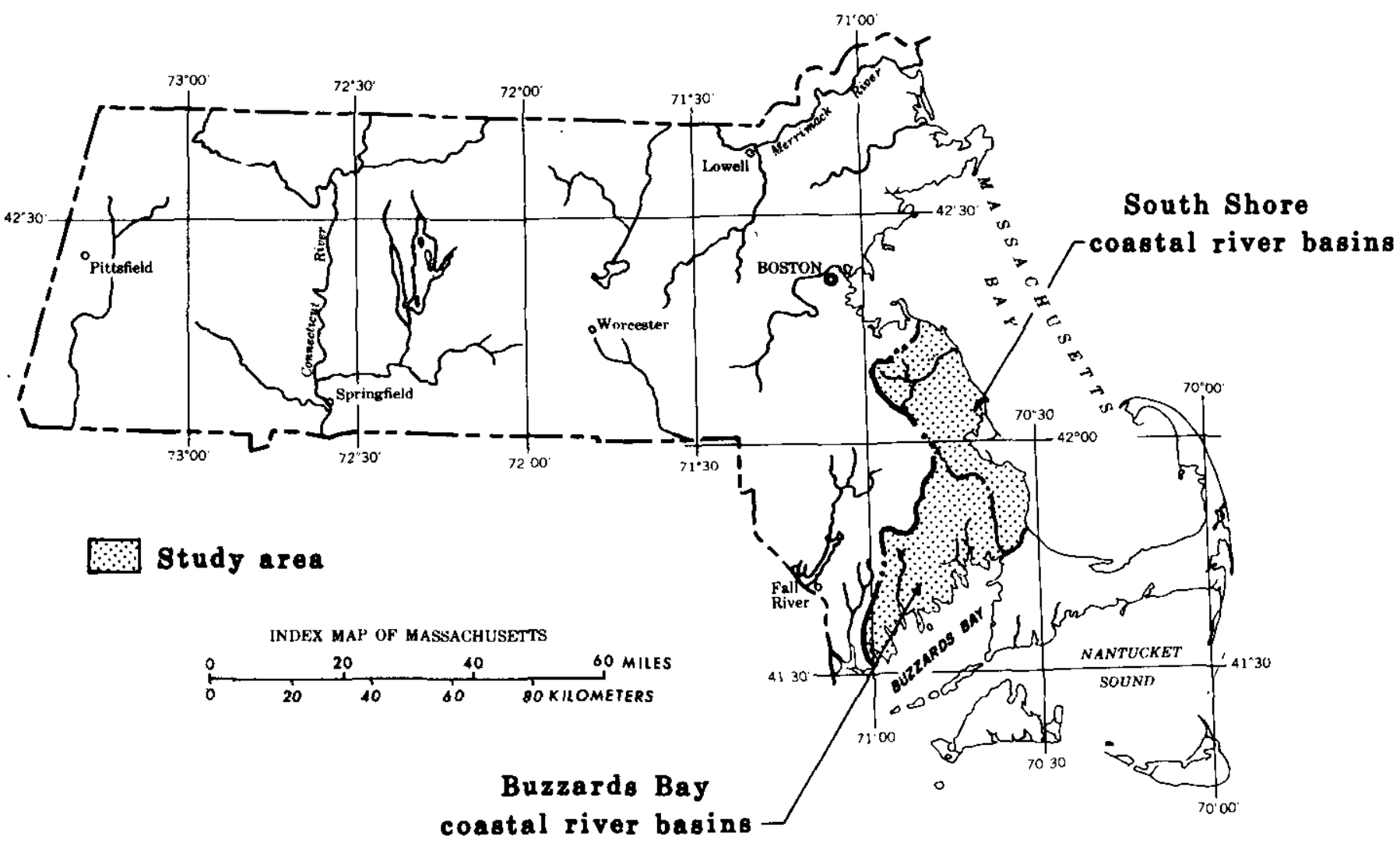

Figure 1.--Location of the coastal river basins of the South Shore and Buzzards Bay 


\section{HYDROLOGIC DATA}

Hydrologic characteristics are represented by various physical, climatic, and streamflow indices of a river basin. These characteristics can be determined either from available maps by following standardized procedures or from historic streamflow records.

Basin characteristics are indices of the physiography of the basin or of the climate prevailing over the basin and are measured on topographic quadrangle or climatic maps. Streamflow characteristics are computed from continuous records of daily flow or from a set of measurements during the occurrence of a specific event. Streamflow and basin characteristics are used in modeling stream quality, assessing water-resources conditions, analyzing impact of man's activities, and defining relationships to estimate flows or stream-quality parameters at ungaged sites.

\section{Basin Characteristics}

Drainage area is one of the most important variables in any hydrologic investigation or in the design of riverine structures because it is the most significant variable in the nor theast that influences all streamflow, except perhaps low flow in some regions. The physical boundary for many water-related studies corresponds to the limits for the drainage area upstream from the site.

For this study, drainage areas listed in table 1 (at the end of the report) were determined for the following sites:

1. Survey data-collection sites shown in figures 2 and 3 . These sites include continuous-record gaging stations given in table 2 (at the end of the report), low-flow partial-record stations, miscellaneous sites, and water-quality stations.

2. Locations where the drainage area is greater than $3 \mathrm{mi}^{2}$.

3. Successive sites along a stream where the area between sites is at least $6 \mathrm{mi}^{2}$ on tributary streams and $10 \mathrm{mi}^{2}$ on the main river.

The drainage basin divides for these sites were delineated on the latest available 1:24,000 scale topographic quadrangle maps. Subbasin drainage divides are shown in the series of statewide reports, "Drainage Divides, Massachusetts." The coastal river basins of the South Shore and Buzzards Bay are covered by two reports in this series--Ipswich and lower Merrimack River basins and northeast coastal basins (Brackley and Wandle, 1983) and Taunton River basin and southeast coastal basins (Wandle and Frimpter, 1982).

The subbasin drainage areas given in table 1 are indexed to the Massachusetts stream inventory prepared by the Massachusetts Division of Water Pollution Control and the Massachusetts Division of Fisheries and Wildlife (Halliwell and others, 1982) with some modification. Drainage areas were computed for sites meeting one of the three criteria mentioned above. The entire stream listing is included as a reference for stream order. This hierarchical listing begins at the mouth of a major stream and proceeds upstream with tributary streams indented under the main-stem stream. This order is followed to list all the named streams. Unnamed tributaries are included to maintain the hierarchy. The reader is referred to the inventory of rivers and streams report by Halliwell and others (1982) for a more detailed explanation.

The basin characteristics listed below are included because they represent indices that would remain reasonably stable over a planning period. They are useful in predictive surfacewater models to assess impacts of proposed developments. The usefulness of these characteristics to explain the variability of various streamflow events has been demonstrated in hydrologic analyses (Thomas and Benson, 1970) and they can be measured readily from available maps. The selected basin indices given in table 3 (at the end of the report) were computed according to the procedures described below. The indices for elevation, storage, lake area, and forest can be computed by the grid method which is explained after all the procedures are described. 


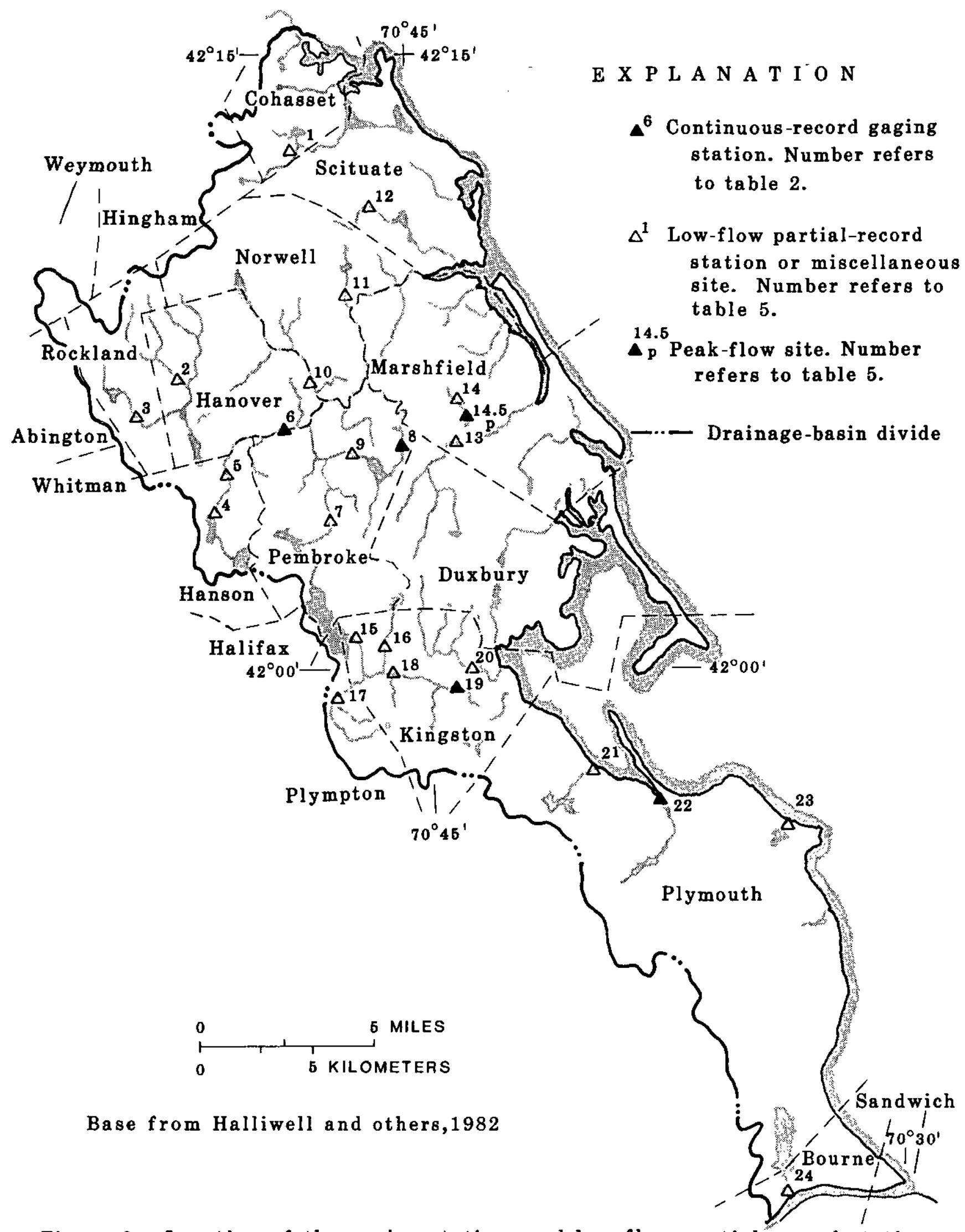

Figure 2.--Location of the gaging stations and low-flow partial-record stations and miscellaneous sites in the coastal river basins of the South Shore 

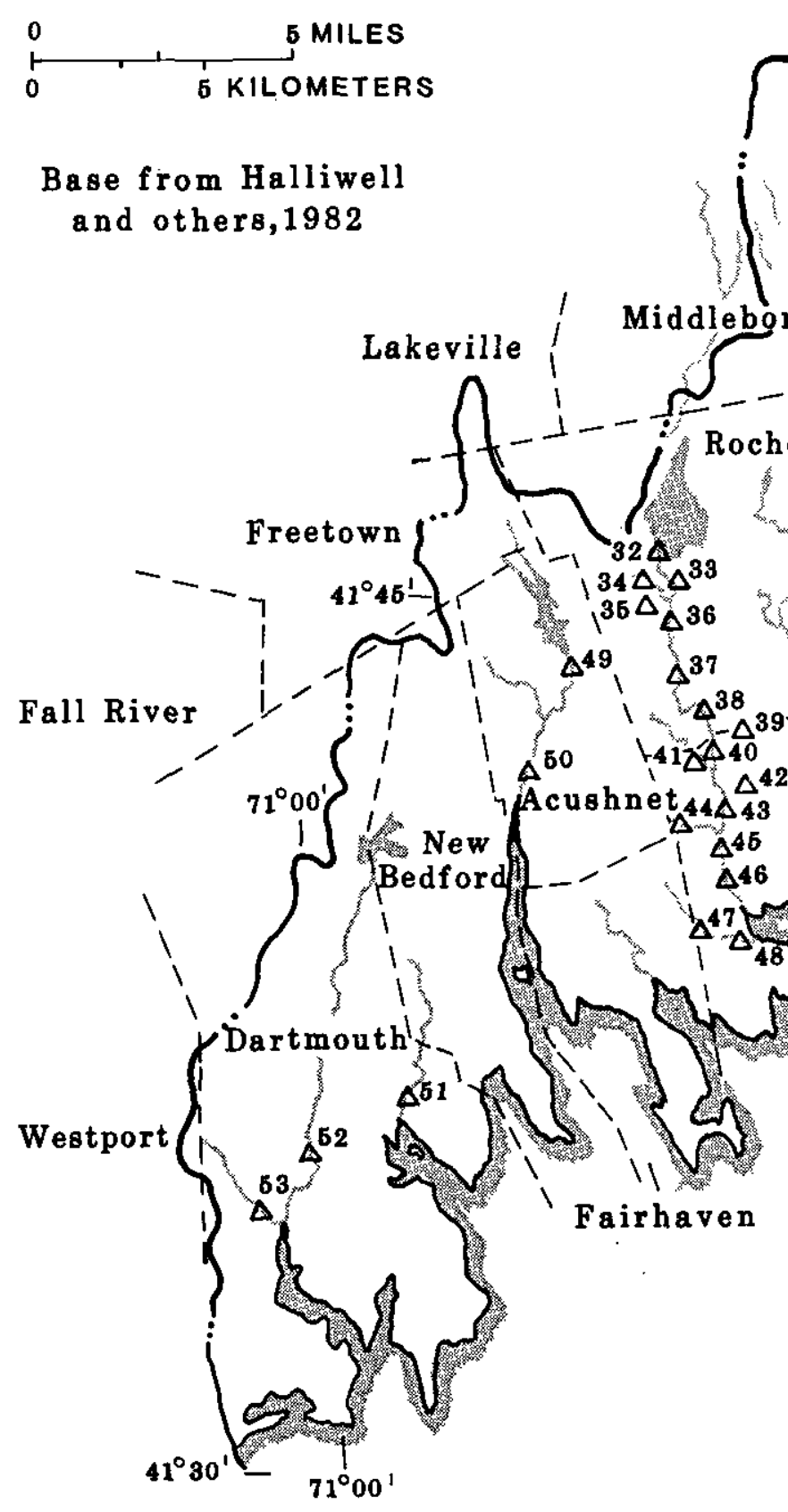
1. Drainage area-Area, in square miles, as measured on the most recent $1: 24,000$ scale topographic quadrangle maps. Drainage area, as defined in the "National Handbook of Recommended Methods for Water-Data Acquisition" (U.S. Geological Survey, 1977), is "...the area of a river basin, measured in a horizontal plane, that is enclosed by a topographic divide such thāt direct surface runoff from précipitation normälly would drain by gravity into the river basin.". Drainage area boundary lines are traced on topographic maps along divides indicated by contour elevations, starting at the point on the stream for which the drainage area is desired. These lines are drawn to cross a contour at right angles. Interpolation between contours may be indicated by reference to trails, old roads, or firebreaks in forested areas, all of which frequently follow drainage divides. Detailed information may also be obtained from highway or street profiles, from examination of aerial photographs, and from ground reconnaissance. Subareas within each quadrangle map were computed with an electronic digitizer using the procedures of the U.S. Federal Inter-Agency River Basin Committee (1951) as a guide. The coefficients to compute square miles from digitizer units were calculated using the known area of each 7.5-minute quadrangle or of the appropriate 2.5-minute quadrilaterals. Drainage areas for the subbasins were computed by summing the contributing areas.

2. Slope-Main-channel slope, in feet per mile, determined from elevations at points 10 percent and 85 percent of the distance along the main channel from the gaging station to the basin divide.

3. Length-Main-channel length, in miles, from the gaging station to the basin divide, as measured with dividers set to 0.1 mile or with a map measurer.

4. Elevation-Mean basin elevation, in feet above sea level, measured on topographic maps by laying a grid over the map.

5. Storage-Area of lakes, ponds, and marshes, in percent of total drainage area, measured by planimetering or by using a transparent grid. The marsh area includes the area of wooded marshes and marshes as defined by the appropriate topographic quadrangle map symbol. Storage area is the total area of all the lakes, ponds, and marshes expressed as a percentage of the total drainage area.

6. Lake area-Area of lakes and ponds, in percent of the drainage area, determined by the grid method.

7. Forest-Area of forest, in percentage of the drainage area, determined from the forest cover as shown on the topographic map with the green woodland overprint using the grid method.

8. Soil-Soil index, in inches, represents the value of potential maximum infiltration, during an annual flood, under average soil-moisture conditions. This characteristic, provided by the U.S. Soil Conservation Service (Dr. Benjamin Isgur, written commun., 1970), is a function of the soil and cover conditions in the basin. The index was computed from the runoff curve number following procedures in U.S. Department of Agriculture (1972).

9. Latitude--Latitude of stream-gaging station, in decimal degrees, determined by manual measurement.

10. Longitude-Longitude of stream-gaging station, in decimal degrees, determined by manual measurement.

11. Precipitation-Mean-annual precipitation, in inches, determined from the isohyetal map in Knox and Nordenson (1955). The variation in mean-annual precipitation is shown in more detail in this map than in more recent sources.

12. Precipitation intensity-Maximum 24-hour rainfall, in inches, having a recurrence interval of 2 years. This characteristic was determined from U.S. Weather Bureau (1959b).

13. Snowfall--Average total seasonal snowfall, in inches, from an isohyetal map in Lautzenheiser (1969).

14. January temperature-Minimum January temperature, in degrees Fahrenheit, determined from U.S. Weather Bureau, (1959a). 
Several basin characteristics were measured following the grid method by using transparent grids to compute area or an average contour value. Storage area is determined by randomly placing the grid over the water and marsh area and counting squares. If the water and marsh area is large enough (about 30 squares), the number of grid intersections within the storage area are counted. The storage area then is computed as the product of the square size and the number of grid intersections. To measure a contour value such as elevation, the grid spacing is selected to give at least 25 intersections within the basin boundary. The elevation at each grid intersection is determined and an average is computed. The percentage of a variable that is extensive in a drainage basin, such as forest cover, can be easily measured by counting the number of grid intersections occurring over the forested area, multiplying by 100 , and dividing by the number of grid intersections within the basin.

\section{Streamflow Characteristics}

The available historic daily flow records were used to compute daily, monthly, and annual flow characteristics. A summary of these streamflow records is given in table 2 and the location of streamflow sites is shown in figures 2 and 3. These flow data were collected as part of the Survey's nationwide data-collection network through agreements with State and Federal agencies. Records of daily flow are available from the Survey's National Water Data Storage and Retrieval System (WATSTORE). This water-data computer processing system consists of several files containing data grouped by common characteristic and data-collection frequency.

The WATSTORE system includes site identification, daily values files, and computer programs that produce streamflow statistics. Hydrologic-data files are maintained for (1) parameters measured on a daily or continuous basis, such as streamflow values, river stages, water temperatures, specific conductance values, and ground-water levels; (2) annual peak values for streamflow and stage; (3) chemical analyses for surface- and ground-water sites; and (4) groundwater site inventory, including location, identification and geohydrologic characteristics. The data-processing, storage, retrieval, and analysis capabilities of WATSTORE are described in the system user's guide compiled by Hutchison (1975). Information on the availability of data analyses may be obtained from: U.S. Geological Survey, 150 Causeway Street, Suite 1309, Boston, MA 02114.

A brief description of the streamflow statisties computed using the WATSTORE system is included below. Streamflow characteristics representing annual, monthly, and daily flow statistics were selected for this analysis because they are useful in planning and design studies in this region. The streamflow statistics computed following the procedures given below are listed in table 4 (at the end of the report).

Annual and monthly flow characteristics (means and standard deviations) were computed for six gaging stations with the "Daily Values Monthly and Annual Statistics" computer program W4422 (Price and Meeks, 1977) using observed daily flow records. The maximum and minimum, monthly means (fig. 4 and table 4) were obtained from output provided by this program. The monthly hydrograph for the Indian Head River at Hanover is shown in figure 4.

Characteristics of the flow-duration curve (the daily flow exceeded 99, 95, 90, 75, 70, 50, 25, and 10 percent of the time) for six gaging stations were computed by means of computer program A969, "Daily Values Statistics" (Meeks, 1977). The flow-duration curve for the Indian Head River at Hanover is given in figure 5. Low-flow characteristics (annual 7-day mean low flows at the 2-year and 10-year recurrence intervals (7Q2 and 7Q10, respectively) at four gaging stations were also calculated by program A969. In this program, a log-Pearson Type III distribution is fitted to a set of observed annual 7-day mean low flows to obtain coordinates of the computed low-flow frequency curve. If the log-Pearson Type III developed curve did not adequately fit a plot of the observed data, especially in the low end, then a graphical curve was drawn. The graphical frequency curve was used to interpret the observed data when necessary because a graphical curve is the basic curve to use in analyzing the frequency of annual low flows according to Riggs $(1971,1972)$. The frequency curve for the Indian Head River at Hanover is shown in figure 6.

Additional flow data, including flood-frequency analyses, are available from WATSTORE. Peak discharges for selected recurrence intervals for 82 sites in Massachusetts are given in Wandle (1982). 


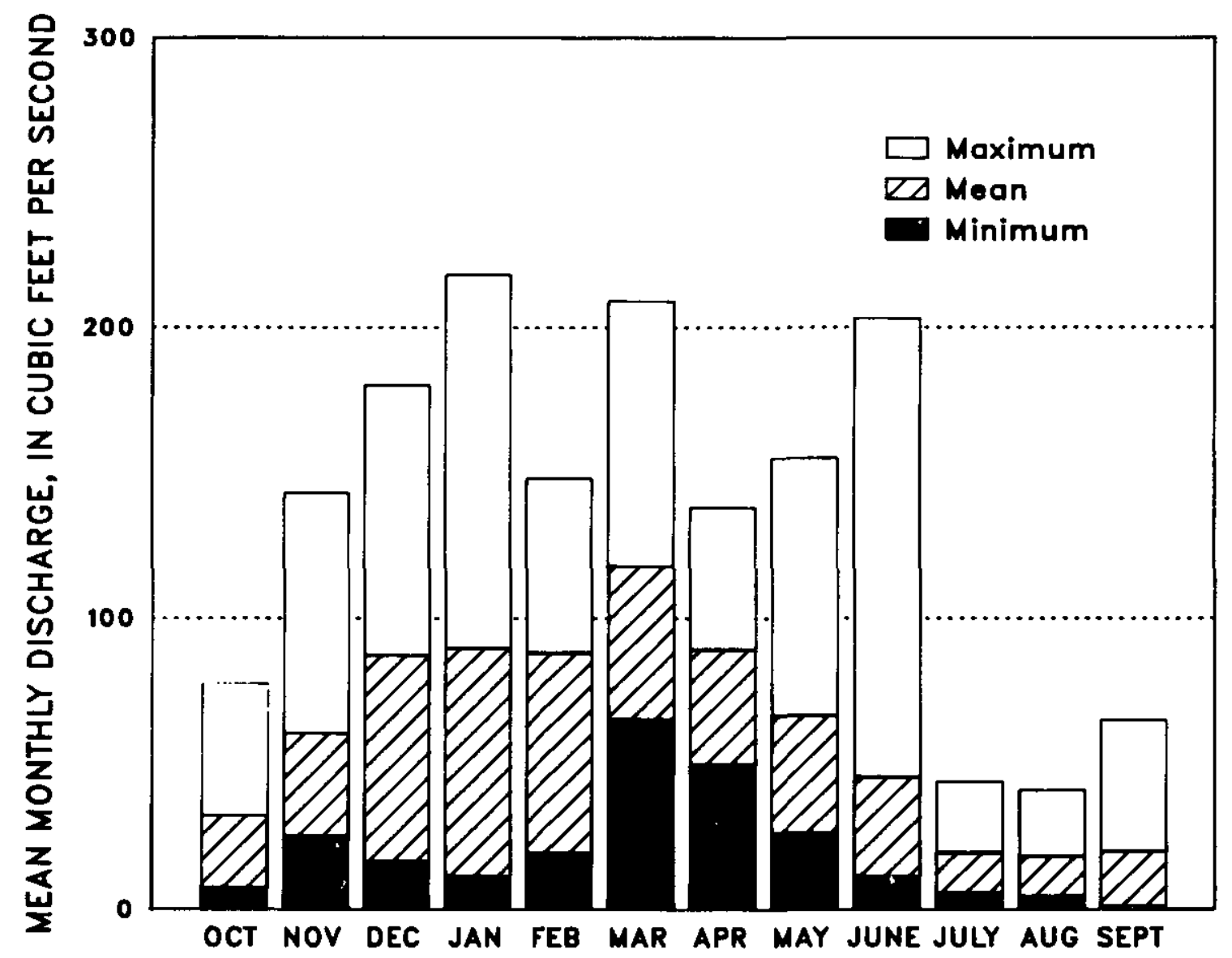

Figure 4.--Monthly discharges and extremes for the Indian Head River at Hanover, Mass. (site 6), during 1967-82 


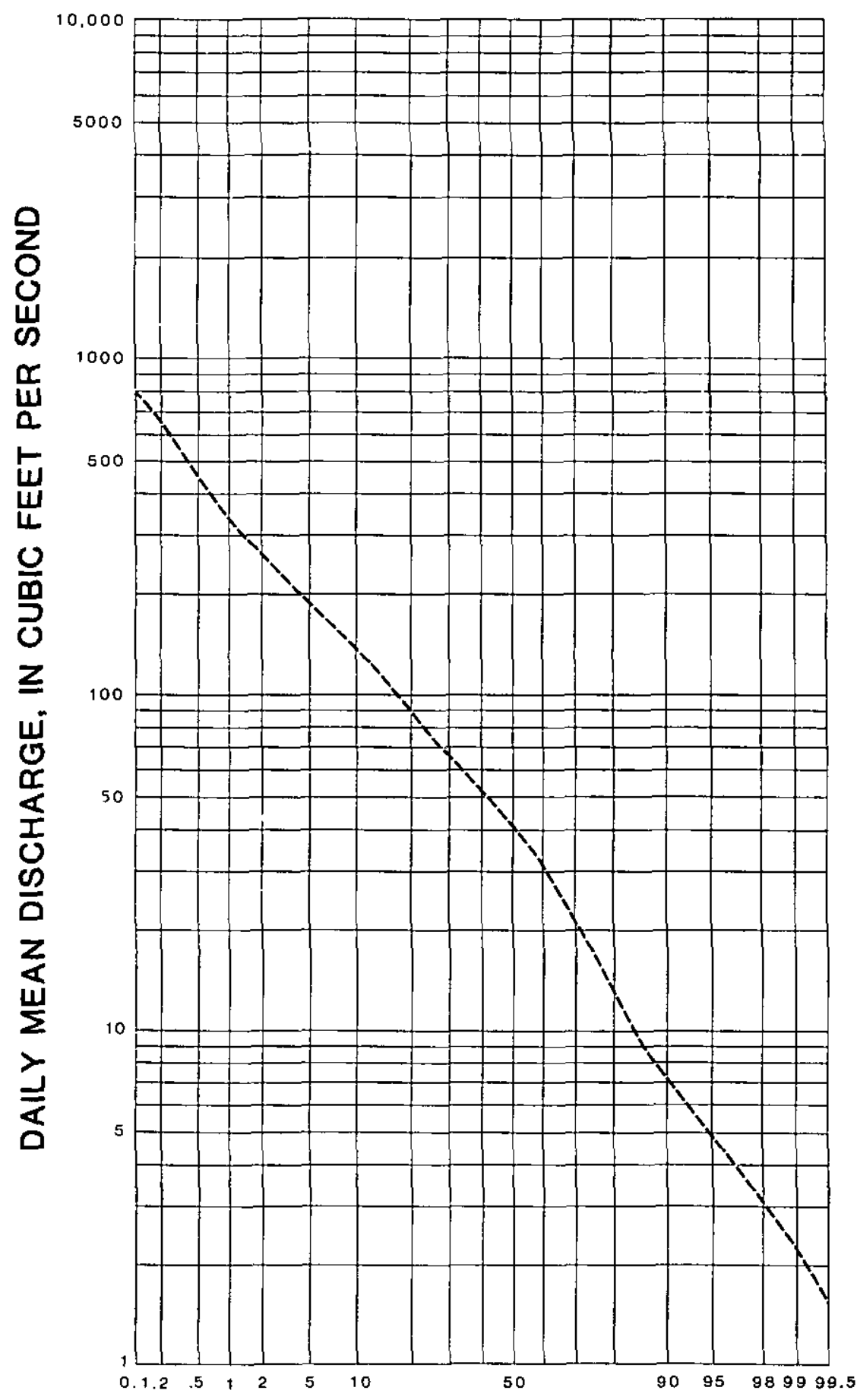

\section{PERCENTAGE OF TIME INDICATED DISCHARGE WAS EQUALED OR EXCEEDED}

Figure 5.--Flow-duration curve for the Indian Head River at Hanover, Mass. (site 6), during 1967-82 


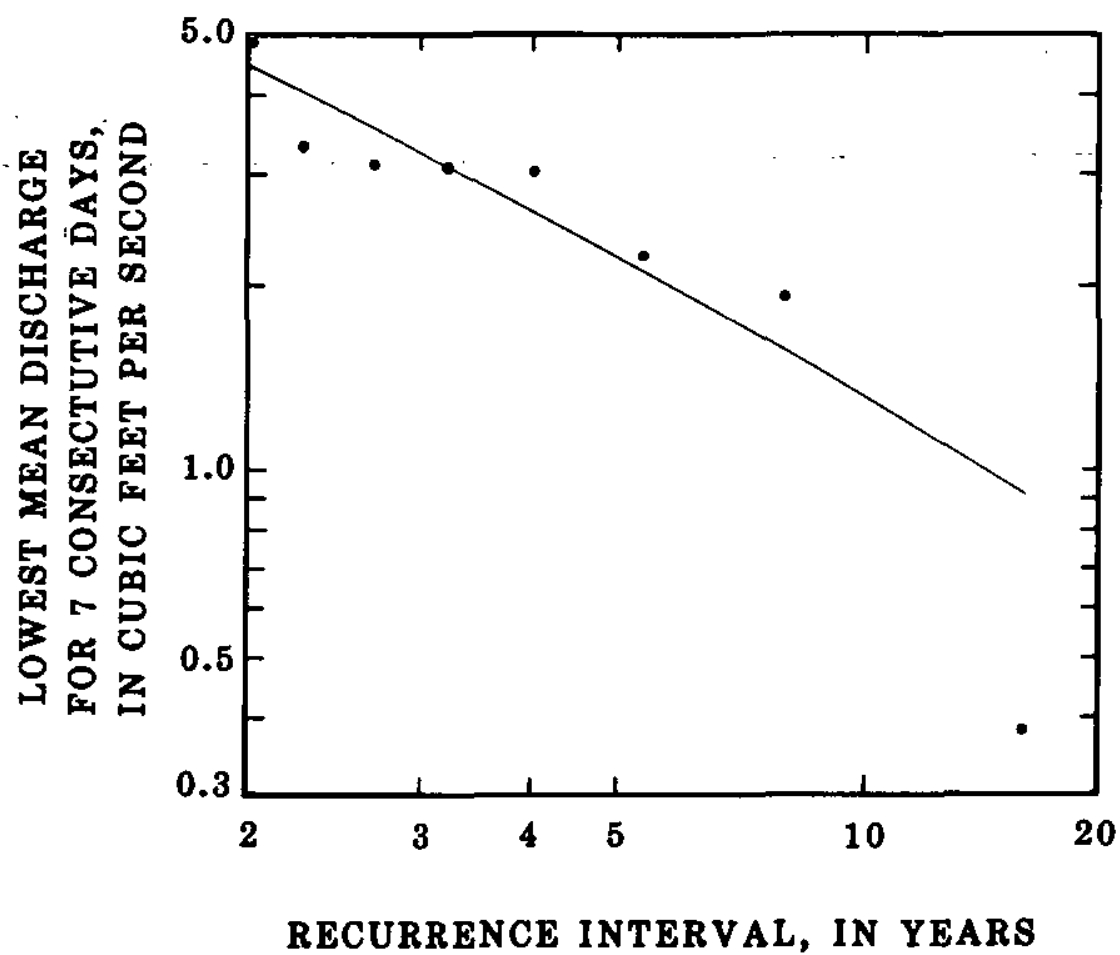

Figure 6.--Low-flow frequency curve for the Indian Head River at Hanover, Mass. (site 6), during 1968-82

Characteristics of low flow were also determined at low-flow partial-record stations where measurements of discharge, rather than a continuous daily flow record, were available. This estimating technique is briefly described in the section on Streamflow Analysis. The 7-day low-flow statistics were developed from discharge measurements made during periods of base runoff. Base runoff is defined (Langbein and Iseri, 1960) as "the sustained or fair weather runoff. In most streams, base runoff is composed largely of ground-water effluent." Base runof $f$ usually occurs in most Massachusetts streams during the summer or early fall after 5 to 7 consecutive days without rainfall.

\section{STREAMFLOW ANALYSIS}

\section{Streamflow Data Base}

Systematic records of daily streamflow have been collected since 1967 for Indian Head and Jones Rivers. Short-term daily flow records are available for other streams in the coastal river basins. The location and period of record for these gaging stations are given in table 2.

Discharge measurements were made at 32 low-flow partial-record sites during the waterresources investigations of southeastern Massachusetts (Williams and Tasker, 1974a, 1974b, 1978). Measurements were also collected as part of the Massachusetts low-flow network at one site from 1978 to 1979 and at nine sites during 1965. Discharge measurements were made at four sites during an investigation of the geology and ground-water resources of the BrocktonPembroke area (Petersen and Shaw, 1961). Additional discharge measurements were collected on the Mattapoisett River and its tributaries during 1982 to aid in the development of a digital ground-water-flow model of the Mattapoisett River Valley aquifer (Olimpio and de Lima, 1984).

Flow characteristics are useful in resource management and design studies if these variables represent a particular regulated flow sequence or the natural flow regime that is expected to occur in the future. A valid streamflow analysis is based upon flow records during a period of relatively constant river-basin conditions. 


\section{Daily Flow Statistics}

Systematic daily flow records for the seven sites given in table 2 were reviewed to select a data base for statistical analysis. Impact of reservoirs, diversions, regulation, and withdrawals for public supplies on streamflows were assessed using information on stream regulation found in the series of water-resources data reports issued annually (see U.S. Geological Survey, 1980, for an example) and in Knox and Soule (1949). Streamflow records for six gaging stations were selected that represent a flow regime influenced by fairly constant river-basin conditions (Wandle, 1983). The record length used in this analysis is given in table 4. Low flow, monthly flow, and flow-duration characteristics given in table 4 were derived from the observed streamflow records at each station and were not adjusted for regulation or diversion. These daily streamflow characteristics were computed following procedures summarized in the section on streamflow characteristics.

\section{Low-Flow Statistics}

Continuous streamflow records are not necessary to estimate low-flow characteristics at sites. According to Riggs (1972) selected base-flow measurements rather than a continuous daily flow record can define the low-flow characteristics at a site.

Low-flow partial-record stations are operated to collect discharge measurements when streamflow is composed largely of ground-water runoff. These low-flow sites are selected on streams where flow is expected to occur during a significant dry spell and where the flow is not affected by artificial regulation. Base-flow measurements to define a relation with concurrent gaged flows are obtained over several low-flow periods.

A relation is developed with the base-flow measurements and the concurrent daily mean flows at a nearby long-record gaging station (index station). The 7-day low-flow statistics (7Q2 and $7 Q 10)$ for the site are determined from this relation using the appropriate low-flow statistics for the gaged stream. This estimating technique is explained in more detail by Riggs (1972).

An analysis of the 7-day low flows for the index stations indicated that the values were essentially the same for Williams and Tasker $(1974 a, 1974 b, 1978)$ and for the current period. Low-flow relationships at the partial-record stations were not redefined except for Mattapoisett River because additional low-flow measurements were not available and because statisties for the index stations did not significantly change. Low-flow estimates for the three Mattapoisett sites were revised using the 1982 data. Information collected as part of the study by Olimpio and de Lima (1984) indicated that the streamflow loss in Williams and Tasker (1978) from site 43 to 46 is based upon unusually large losses in that reach.

Low-flow statistics for 49 sites in the coastal river basins of the South Shore and Buzzards Bay are summarized in table 5 (at the end of the report). The low-flow statistics are representative of the hydrologic regime during the data-collection period. Seven-day, 2-year, and 10-year low flows ranged from 0 to 1.47 and from 0 to $1.17\left(\mathrm{ft}^{3} / \mathrm{s}\right) / \mathrm{mi}^{2}$, respectively, at the 49 partialrecord stations. Nearby, long-term gaging stations were used as the index stations. These values were computed by Williams and Tasker $(1974 \mathrm{a}, 1974 \mathrm{~b}, 1978)$ following the procedures mentioned above.

\section{SUMMARY}

Drainage areas were re-computed for data-collection sites and were computed for the first time for ungaged streams draining greater than $3 \mathrm{mi}^{2}$. Basin characteristics for drainage area, slope, length, elevation, storage, lake area, forest, soil, latitude, longitude, precipitation, precipitation intensity, snowfall, and January minimum temperature are provided. Computer programs A969 and W4422 were used to determine daily flow statistics including annual and monthly flows, duration of daily flows, and 7-day low-flow values. Seven-day, 2-year, and 10-year low flows ranged from 0 to 1.47 and from 0 to $1.17\left(\mathrm{ft}^{3} / \mathrm{s}\right) / \mathrm{mi}^{2}$, respectively, at the 49 partial-record stations.

Techniques used to compute basin and streamflow characteristics of a river basin are summarized. This gazetteer contains a comprehensive listing of hydrologic characteristics that should prove useful to those concerned with water-resources activities. 
Table 1.--Stream-order listing, selected drainage areas, and locations of subbasins within the coastal river basins of the South Shore and Buzzards Bay

[Sites with streamflow information listed in tables 2,4 , or 5 are marked with an astērisk. The hierarchical listing is modified from Halliwell and others, 1982. Drainage areas are shown for sites as explained in the section on basin characteristics.

These areas are not adjusted for manmade changes in the flow system.]

\begin{tabular}{|c|c|c|}
\hline Stream name & Location & $\begin{array}{c}\text { Drainage } \\
\text { area, } \\
\text { in square } \\
\text { miles }\end{array}$ \\
\hline
\end{tabular}

Richardsons Brook

COASTAL BASINS OF THE SOUTH SHORE

James Brook

Bailey Creek

The Gulf

Bound Brook

200 feet below Hunters Pond

11.4

Herring Brook

Brass Kettle Brook

Bound Brook

Doane Street

$* 4.86$

Aaron River

Musquashcut Brook

Satuit Brook

North and South Rivers

North River

Macombers Creek

Hannah Eames Brook

Bares Brook

Herring River

First Herring Brook

First Herring Brook

Cove Brook

Stony Brook

North River

Second Herring Brook

Robinson Creek

Third Herring Brook

Copeland Tannery Brook

Third Herring Brook

Third Herring Brook

Wildcat Creek

Wildeat Brook

Silver Brook

Mollys Brook

Herring Brook

Swamp Brook

Pudding Brook MeFarland Brook

Pudding Brook Huldah Brook

Combined mouths

105

Maple Street

1.83

Grove Street

$* 1.74$

Bridge Street

70.1

State Street 123

*3.15

River Street

$* 9.78$

Jacobs Pond outlet

1.71

State Route 53

$* 4.52$

Spring Street

a1.38

Little Pudding Brook

Herring Brook

Mountain Avenue

$* 5.58$ 
Table 1.--Stream-order listing, selected drainage areas, and locations of subbasins within the coastal river basins of the South Shore and Buzzards Bay (Continued)

Stream name Location

Drainage area, in square miles

COASTAL BASINS OF THE SOUTH SHORE (Continued)

North River (Continued)

Indian Head River Iron Mine Brook Indian Head River

Rocky Run Indian Head Brook Indian Head Brook

Elm Street

$* 30.2$

Drinkwater River Torrey Brook

Drinkwater River

French Stream

Cushing Brook Ben Mann Brook

Longwater Brook Shinglemill Brook

South River

Washington Street

$* 4.30$

Wampatuck Pond outlet

*2.53

Forge Pond inlet

10.7

Summer Street

$* 4.98$

State Route 139

$* 4.15$

Trouant Island

Branch Creek

Broad Creek

Littles Creek

Unnamed tributary

Furnace Brook

Furnace Brook

South River

Unnamed tributary

Keene Brook

Harlow Brook

Philips Brook

Green Harbor River

Wharf Creek

Bass Creek

Green Harbor Brook

Back River

Great Wood Island River

Pine Point River

Cut River

Lit tle Wood Island River

Duck Hill River

Bourne Wharf River

Dug Way

West Brook

Bluefish River

Island Creek

Jones River

Unnamed tributary

Mouth

29.6

$\begin{array}{lr}\text { School Street } & * .94 \\ \text { Furnace Street } & * 1.56\end{array}$

Old Ocean Street $\quad * 7.59$

State Route 139

Smelt Brook 
Table 1.--Stream-order listing, selected drainage areas; and locations of subbasins within the coastal river basins of the South Shore and Buzzards Bay (Continued)

\begin{tabular}{|c|c|c|}
\hline Stream name & Location & $\begin{array}{c}\text { Drainage } \\
\text { area, } \\
\text { in square } \\
\text { miles }\end{array}$ \\
\hline
\end{tabular}

COASTAL BASINS OF THE SOUTH SHORE (Continued)

Jones River (Continued)

Halls Brook

600 feet above State Route $3 \mathrm{~A}$

Tussock Brook

Mile Brook

Bassett Brook

Unnamed tributary

Second Brook

Jones River

Elm Street

$* 19.8$

Furnace Brook

Fountainhead Brook

Jones River

Pine Brook

Pine Brook

Jones River Brook

Barrows Brook

Jones River

Tubbs Meadow Brook

Town Brook

Eel River

Unnamed tributary

Beaver Dam Brook

Indian Brook

Herring River

Private road

*10.6

Grove Street

75 feet below State Route 27

$\mathrm{b} * 3.14$

State Route 106

$* 3.57$

Silver Lake outlet

$* 4.09$

Mouth

$* 9.04$

State Route 3A

*14.7

800 feet above mouth $\quad * 5.52$

Mouth

$* 7.74$

COASTAL BASINS OF BUZZARDS BAY

Red Brook

Red Brook Road

$* 9.84$

East River

Gibbs Brook

Bass Creek

Wareham River

Cedar Island Creek

Crooked River

Broad Marsh River

Stony Run

Agawam River

Maple Springs Brook

800 feet below Mill Pond

$* 17.1$.

East Branch

Agawam River

Wankinco River

Rose Brook

Harlow Brook

Frogfoot Brook

600 feet below Halfway Pond outlet

*6.71

1000 feet below Parker Mills Pond

*20.5 
Table 1.--Stream-order listing, selected drainage areas, and locations of subbasins within the coastal river basins of the South Shore and Buzzards Bay (Continued)

Stream name Location

Drainage

area,

in square

miles

COASTAL BASINS OF BUZZARDS BAY (Continued)

Weweantic River

Beaverdam Creek

Sippican River

County Road

$* 28.1$

Cohackett Brook

Hales Brook

Benson Brook

Doggett Brook

Sherman Brook

East Branch Sippican River

West Branch Sippican River

Weweantic River

Crane Brook

Indian Brook

Sampson Brook

Tilson Brook

Double Brook

East Rocky Gutter Brook

West Rocky Gutter Brook

Rocky Meadow Brook

South Meadow Brook

Beaver Dam Brook

Aucoot Creek

Mat tapoisett River

Mat tapoisett River

Mattapoisett River

Branch Brook

Mat tapoisett River

Mat tapoisett River

Mat tapoisett River

Mattapoisett River

Swift Brook

Swift Brook

Nasketucket River

Acushnet River

Acushnet River

Deep Brook

Acushnet River

Acushnet River

Keene River

Squam Brook Ashley Brook

Buttonwood Brook

Little River

U.S. Route 6

0.4 mile above U.S. Route 6

Acushnet Road

Tinkham Lane

Squire Island Road

*56.1

$* 2.71$

$* 24.0$

*23.5

$* 18.2$

Wolf Island Road

New Bedford Road

Rounseville Road

Snipatuit Road

14.1

*13.1

$* 11.2$

6.45

0.1 mile above Mattapoisett Neck Road $\quad * 1.18$

U.S. Route 6

$* .78$

Main Street

18.7

Hamlin Road

*16.4

Road 1 mile below Leonard Street

10.1

Leonard Street

*7.52

Russells Mills Road

$* 2.93$ 
Table 1.--Stream-order listing, selected drainage areas, and locations of subbasins within the coastal river basins of the South Shore and Buzzards Bay (Continued)

Stream name Location

Drainage area, in square miles

\section{COASTAL BASINS OF BUZZARDS BAY (Continued)}

Slocums River

Mouth

Giles Creek

Peter Creek

Destruction Brook

Slades Corner Road

$* 2.64$

Paskamanset River

Fisher Road

28.5

Paskamanset River

Russells Mills Road

$* 26.2$

Paskamanset River

2.5 miles above Russells Mills Road

20.0

Paskamanset River

U.S. Route 6

15.9

Paskamanset River

Turner Pond outlet

a From U.S. Geological Survey, 1964.

b From Petersen, 1962. 
Table 2.-Summary of daily flow records available in the coastal river basins of the South Shore and Buzzards Bay

\begin{tabular}{|c|c|c|c|c|c|}
\hline $\begin{array}{l}\text { Number } \\
\text { in } \\
\text { figures } \\
2 \text { and } 3\end{array}$ & $\begin{array}{l}\text { Station } \\
\text { number }\end{array}$ & Station name & Location & $\begin{array}{l}\text { Period } \\
\text { of } \\
\text { record }\end{array}$ & Remarks \\
\hline 1 & 01105660 & $\begin{array}{l}\text { Bound Brook near } \\
\text { Cohasset, Mass. }\end{array}$ & Doane Road & 1971 & Discontinued. \\
\hline 5 & 01105700 & $\begin{array}{l}\text { Indian Head Brook } \\
\text { near Hanson, Mass. }\end{array}$ & $\begin{array}{l}\text { Washington } \\
\text { Street }\end{array}$ & $1959-60$ & $\begin{array}{l}\text { Some regulation by ponds. } \\
\text { Discontinued. }\end{array}$ \\
\hline 6 & 01105730 & $\begin{array}{l}\text { Indian Head River } \\
\text { at Hanover, Mass. }\end{array}$ & Elm Street & 1967-82 & $\begin{array}{l}\text { Some regulation by mills } \\
\text { and ponds. Water-quality } \\
\text { records } 1970-71 \text {. }\end{array}$ \\
\hline 8 & 01105800 & $\begin{array}{l}\text { Pudding Brook at } \\
\text { East Pembroke, Mass. }\end{array}$ & Spring Street & $1959-62$ & $\begin{array}{l}\text { Regulated by Randall } \\
\text { Pond. Discontinued. }\end{array}$ \\
\hline 14.5 & 01105850 & $\begin{array}{l}\text { Furnace Brook near } \\
\text { Marshfield, Mass. }\end{array}$ & Furnace Street & $1964-82$ & Peak-flow site. \\
\hline 19 & 01105870 & $\begin{array}{l}\text { Jones River at } \\
\text { Kingston, Mass. }\end{array}$ & Elm Street & $1967-82$ & $\begin{array}{l}\text { Regulated by pond up- } \\
\text { stream. Flow from } \\
\text { Silver Lake diverted } \\
\text { for municipal supplies } \\
\text { of Brockton, Whitman, } \\
\text { and Hanson. Flow } \\
\text { affected at times } \\
\text { during spring by wast- } \\
\text { age from Silver Lake. } \\
\text { Surface flow may be } \\
\text { affected by ground } \\
\text { water that enters from } \\
\text { or moves into adjacent } \\
\text { basins. Water-quality } \\
\text { records } 1970-71 \text {. }\end{array}$ \\
\hline 22 & 01105876 & $\begin{array}{l}\text { Eel River near } \\
\text { Plymouth, Mass. }\end{array}$ & State Route $3 \mathrm{~A}$ & $1970-71$ & $\begin{array}{l}\text { Surface flow may be } \\
\text { affected by ground } \\
\text { water that enters from } \\
\text { or moves into adjacent } \\
\text { basins. Water-quality } \\
\text { records. Discontinued. }\end{array}$ \\
\hline 29 & 01105895 & $\begin{array}{l}\text { Weweantic River at } \\
\text { South Wareham, } \\
\text { Mass. }\end{array}$ & $\begin{array}{l}\text { Squire Island } \\
\text { Road }\end{array}$ & $1970-71$ & $\begin{array}{l}\text { Some regulation by } \\
\text { ponds. Water-quality } \\
\text { records. Discontinued. }\end{array}$ \\
\hline
\end{tabular}


Table 3.--Basin characteristies for selected stream-gaging stations in the coastal river basins of the South Shore and Buzzards Bay

Basin

characteristics

Station name and site number
Indian Head Brook Indian Head River Pudding Brook at
Furnace Brook near Hanson,
Mass.
at Hanover,
Mass.
East Pembroke, near Marsh- Mass.
field, Mass.

(5)

(6)

(8)

(14.5)

Area, in square miles

4.30

30.2

a1.38

1.56

Slope, in feet per mile

一
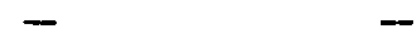

2.5

Length, in miles

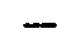

$-$

一

2.7

Elevation, in feet

$-$

$-$

$-$

160

Storage, in percent

$-$

$-$

Lake area, in percent

-

Forest, in percent

$-$

$-$

$-$

0

$-$

0

Soils index, in inches

$-$

$-$

$-$

95

Latitude of gage, in decimal degrees

42.0869

42.0337

42.0305

42.1083

Longitude of gage, in decimal degrees

70.8572

70.8231

70.7578

70.7314

Precipitation, in inches

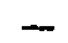

44.0

Precipitation intensity for 2-year recurrence interval, in inches

Snowfall, in inches
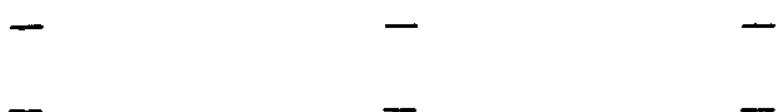

January minimum temperature, in degrees Fahrenheit

-

-

21.0

a From U.S. Geological Survey, 1964. 
Table 3.-Basin characteristics for selected stream-gaging stations in the coastal river basins of the South Shore and Buzzards Bay (Continued)

Basin

characteristics
Station name and site number
Jones River

at

Kingston, Mass.

(19)
Eel River

near

Plymouth, Mass.

(22)
Weweantic River at South

Wareham, Mass.
(29)

Area, in square miles

b15.7

14.7

56.1

Slope, in feet per mile

Length, in miles

Elevation, in feet

Storage, in percent

Lake area, in percent

Forest, in percent

Soils index, in inches

Latitude of gage, in decimal degrees

Longitude of gage, in decimal degrees

Precipitation, in inches

Precipitation intensity for 2-year recurrence interval, in inches

Snowfall, in inches

January minimum temperature, in degrees Fahrenheit

b Excludes $4.09 \mathrm{mi}^{2}$ above Silver Lake outlet. 
Table 4.--Streamflow characteristics, in cubic feet per second, at selected stream-gaging stations

Annual and monthly flow characteristics:

QA is the mean annual discharge

SDQA is the standard deviation of mean annual discharge

$Q M$ is the mean discharge for $M$ calendar month, $M=1$ for January where the top line is the maximum mean; the middle line is the mean; the bottom line is the minimum mean

SDQM is the standard deviation of mean discharge for $M$ calendar month

Low-flow characteristics:

7Q2 is the annual minimum 7-day mean discharge for 2-year recurrence interval

$7 \mathrm{Q} 10$ is the annual minimum 7-day mean discharge for 10 -year recurrence interval

Flow-duration characteristics:

DPT is the daily discharge, exceeded PT percent of the time, from the flow-duration curve Years of record:

YRSDAY is the number of years of daily flow record for this analysis

YRSLOW is the number of years of low-flow record for this analysis

Flow

Station name and site number

$\begin{array}{cccccc}\text { Indian Head } & \text { Indian Head } & \text { Pudding Brook } & & \text { Eel River } & \text { Weweantic } \\ \text { River at } & \\ \text { Brook near } & \text { River at } & \text { at East } & \text { Jones River } & \text { near } & \text { South } \\ \text { Hanson, } & \text { Hanover, } & \text { Pembroke, } & \text { at Kingston, } & \text { Plymouth, Wareham, } \\ \text { Mass. } & \text { Mass. } & \text { Mass. } & \text { Mass. } & \text { Mass. } & \text { Mass. } \\ (5) & (6) & (8) & (19) & (22) & (29)\end{array}$

ANNUAL

QA

61.2

30.4

SDQA

13.5

$-$

54.0

MONTHLY

Q10

6.56

77.5

2.74

$\overline{3.44}$

32.1

7.36

1.85

43.2

17.4

7.95

SDQ10

23.6

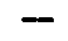

10.2

Q11

\subsection{6}

143

$\overline{5.59}$

60.4

2.61

$-$

25.1

1.92

66.0

27.2

5.71

SDQ11

34.5

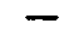

15.0

Q12

8.50

180

87.3

2.54

5.40

16.4

2.15

76.8

35.5

10.8

SDQ12

50.7

21.6 
Table 4.--Streamflow characteristics, in cubic feet per second, at selected stream-gaging stations (Continued)

Flow

Station name and site number

\section{Indian Head Brook near \\ Hanson, \\ Mass.}

(5)
Indian Head Pudding Brook River at Hanover, Mass.

(6) at East Pembroke, Mass.

(8)
Jones River at Kingston, Mass.

(19)
Weweantic Eel River River at near South Plymouth, Wareham, Mass. Mass.

(22)

MONTHLY (Continued)

\begin{tabular}{|c|c|c|c|c|c|c|}
\hline Q1 & $\begin{array}{c}9.28 \\
\overline{4.26}\end{array}$ & $\begin{array}{r}218 \\
89.8 \\
11.4\end{array}$ & $\begin{array}{c}3.33 \\
- \\
1.75\end{array}$ & $\begin{array}{c}78.2 \\
37.6 \\
9.00\end{array}$ & $\begin{array}{r}28.5 \\
24.2\end{array}$ & $\begin{array}{r}139 \\
- \\
64.0\end{array}$ \\
\hline SDQ1 & - & 58.2 & $\therefore-$ & 19.4 & - & - \\
\hline Q2 & $\begin{array}{r}13.7 \\
\overline{6.78}\end{array}$ & $\begin{array}{r}148 \\
88.1 \\
19.4\end{array}$ & $\begin{array}{c}3.19 \\
- \\
2.08\end{array}$ & $\begin{array}{l}66.1 \\
43.1 \\
20.1\end{array}$ & $\begin{array}{r}31.4 \\
30.7\end{array}$ & ${ }^{215}$ \\
\hline SDQ2 & - & 31.0 & - & 12.3 & - & - \\
\hline Q3 & $\begin{array}{r}14.0 \\
13 . \overline{5}\end{array}$ & $\begin{array}{r}209 \\
118 \\
65.3\end{array}$ & $\begin{array}{c}3.48 \\
\overline{3.08}\end{array}$ & $\begin{array}{l}95.0 \\
53.0 \\
31.9\end{array}$ & $\begin{array}{r}31.0 \\
- \\
30.2\end{array}$ & $\begin{array}{c}190 \\
142^{--}\end{array}$ \\
\hline SDQ3 & - & 47.6 & - & 17.9 & - & - \\
\hline Q4 & $\begin{array}{r}14.1 \\
12 . \overline{2}\end{array}$ & $\begin{array}{r}138 \\
89.2 \\
49.8\end{array}$ & $\begin{array}{c}3.71 \\
-\overrightarrow{3.07}\end{array}$ & $\begin{array}{l}61.9 \\
41.7 \\
21.4\end{array}$ & $\begin{array}{r}35.0 \\
25.8\end{array}$ & $\begin{array}{r}179 \\
-- \\
97.7\end{array}$ \\
\hline SDQ4 & - & 25.7 & - & 11.0 & - & - \\
\hline Q5 & $\begin{array}{c}6.43 \\
- \\
5.87\end{array}$ & $\begin{array}{r}155 \\
66.5 \\
26.1\end{array}$ & $\begin{array}{c}3.42 \\
- \\
2.47\end{array}$ & $\begin{array}{l}67.7 \\
36.5 \\
14.9\end{array}$ & $\begin{array}{r}33.1 \\
27.6\end{array}$ & $\begin{array}{r}119 \\
72.5\end{array}$ \\
\hline SDQ5 & - & 35.5 & - & 15.6 & - & - \\
\hline Q6 & $\frac{6.53}{2.63}$ & $\begin{array}{r}203 \\
45.4 \\
11.4\end{array}$ & $\begin{array}{c}2.76 \\
-\overline{1.81}\end{array}$ & $\begin{array}{c}69.3 \\
25.3 \\
9.56\end{array}$ & $\begin{array}{r}31.6 \\
25.7\end{array}$ & $\begin{array}{r}78.6 \\
- \\
55.9\end{array}$ \\
\hline SDQ6 & - & 46.4 & - & 14.3 & - & - \\
\hline Q7 & $\begin{array}{c}7.56 \\
\overline{1.80}\end{array}$ & $\begin{array}{c}43.7 \\
19.4 \\
5.68\end{array}$ & $\frac{2.31}{-}$ & $\begin{array}{c}37.5 \\
15.3 \\
6.34\end{array}$ & $\begin{array}{r}27.7 \\
- \\
23.5\end{array}$ & $\begin{array}{r}46.0 \\
- \\
25.0\end{array}$ \\
\hline SDQ7 & - & 17.5 & - & 7.60 & - & - \\
\hline
\end{tabular}


Table 4.--Streamflow characteristics, in cubic feet per second, at selected stream-gaging stations (Continued)

Flow

Station name and site number

$\begin{array}{cc}\text { Indian Head } & \text { Indian Head } \\ \text { Brook near } & \text { River at } \\ \text { Hanson, } & \text { Hanover, } \\ \text { Mass. } & \text { Mass. }\end{array}$

$\begin{array}{cl}\text { Pudding Brook } & \\ \text { at East } & \text { Jones River } \\ \text { Pembroke, } & \text { at Kingston, } \\ \text { Mass. } & \text { Mass. }\end{array}$

Eel River River at near South

Mass.

(6)

(8)

(19)

Plymouth, Wareham, Mass. Mass.

(5)

)

(22)

(29)

MONTHLY (Continued)

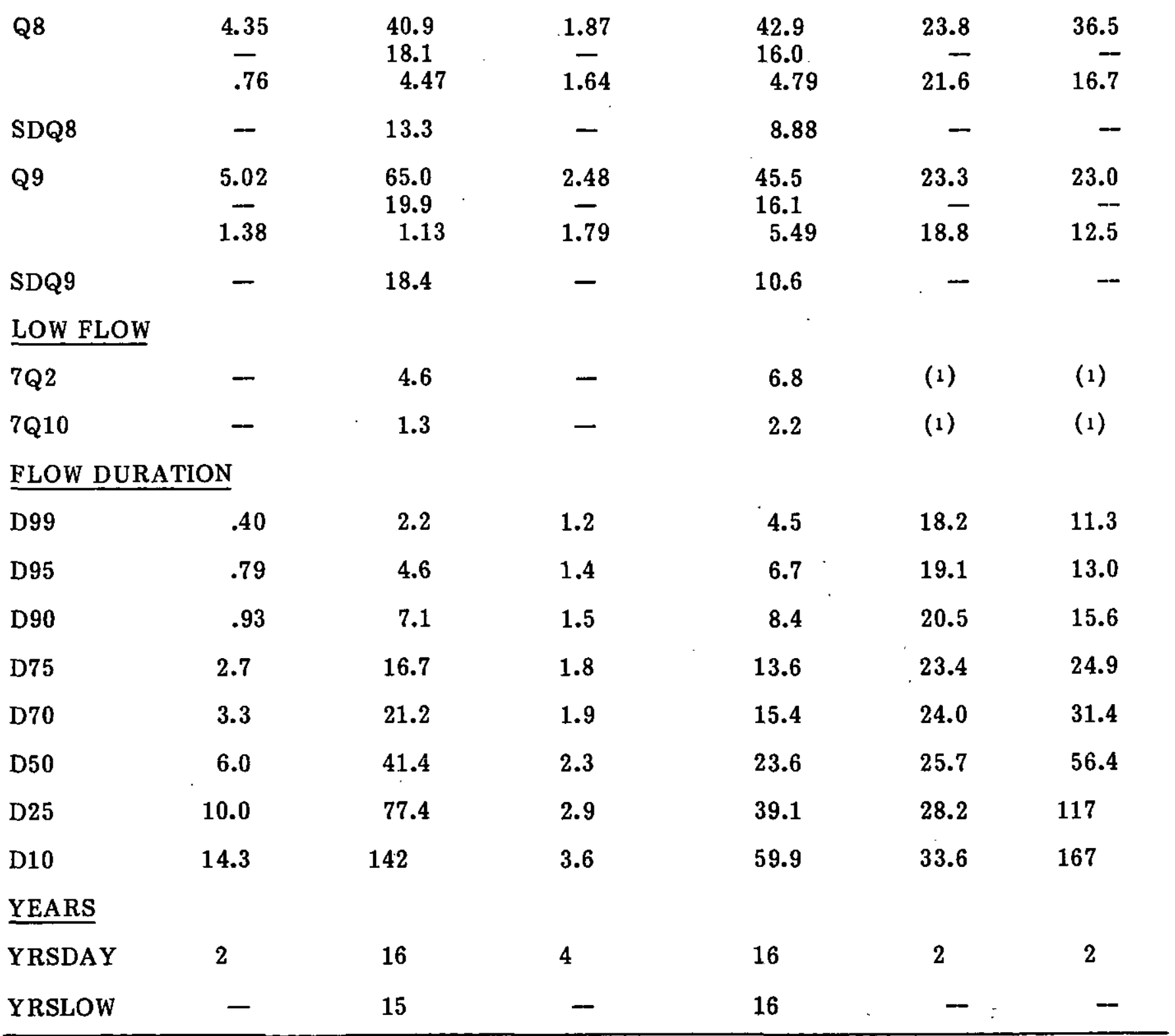

${ }^{1}$ Estimates are given in table 5. 
Table 5.--Summary of 7-day low-flow characteristics, drainage area, and period of record for low-flow partial-record stations and miscellaneous sites

\begin{tabular}{|c|c|c|c|c|c|c|}
\hline $\begin{array}{l}\text { Number } \\
\text { in } \\
\text { figures } \\
2 \text { and } 3\end{array}$ & $\begin{array}{l}\text { Station } \\
\text { number }\end{array}$ & Station name & Location & $\begin{array}{l}\text { Period } \\
\text { of } \\
\text { record }\end{array}$ & $\begin{array}{l}\text { Drainage } \\
\text { area, } \\
\text { in } \\
\text { square } \\
\text { miles }\end{array}$ & $\begin{array}{c}\text { Estimated } \\
\text { annual minimum } \\
7 \text {-day mean } \\
\text { low flow, in } \\
\text { cubic feet per } \\
\text { second, at } \\
\text { indicated } \\
\text { recurrence } \\
\text { interval } \\
\end{array}$ \\
\hline & & & & & & 2-year 10 -year \\
\hline
\end{tabular}

COASTAL BASINS OF THE SOUTH SHORE

\begin{tabular}{|c|c|c|c|c|c|c|c|}
\hline 1 & 01105660 & $\begin{array}{l}{ }^{1} \text { Bound Brook near } \\
\text { Cohasset, Mass. }\end{array}$ & Doane Street & $\begin{array}{l}1969-70 \\
1978-79\end{array}$ & 4.86 & 0.1 & 0.0 \\
\hline 2 & 01105680 & $\begin{array}{l}{ }^{2} \text { Cushing Brook at } \\
\text { West Hanover, Mass. }\end{array}$ & State Route 139 & $1969-71$ & 4.15 & .2 & .0 \\
\hline 3 & 01105690 & $\begin{array}{l}{ }^{2} \text { French Stream } \\
\text { near Rockland, Mass. }\end{array}$ & Summer Street & $1969-71$ & 4.98 & 1.1 & .5 \\
\hline 4 & 01105698 & $\begin{array}{l}\text { Indian Head Brook } \\
\text { at Hanson, Mass. }\end{array}$ & $\begin{array}{l}\text { Wampatuck Pond } \\
\text { outlet }\end{array}$ & $1958-60$ & 2.53 & - & - \\
\hline 5 & 01105700 & $\begin{array}{l}{ }^{\mathrm{I}} \text { Indian Head Brook } \\
\text { near Hanson, Mass. }\end{array}$ & Washington St. & $\begin{array}{l}1965 \\
1969-71\end{array}$ & 4.30 & .5 & .2 \\
\hline 7 & 01105770 & $\begin{array}{l}{ }^{3} \text { Herring Brook at } \\
\text { Pembroke, Mass. }\end{array}$ & Mountain Ave. & $\begin{array}{l}1958-60, \\
1965 \\
1969-71\end{array}$ & 5.58 & 1.0 & .6 \\
\hline 9 & 01105805 & $\begin{array}{l}{ }^{4} \text { Pudding Brook at } \\
\text { North Pembroke, Mass. }\end{array}$ & State Route 53 & $\begin{array}{l}1958-60 \\
1969-71\end{array}$ & 4.52 & .5 & .3 \\
\hline 10 & 01105810 & $\begin{array}{l}\text { Third Herring Brook } \\
\text { at Hanover, Mass. }\end{array}$ & River Street & $1969-71$ & 9.78 & .4 & .0 \\
\hline 11 & 01105820 & $\begin{array}{l}\text { Second Herring Brook } \\
\text { at Norwell, Mass. }\end{array}$ & State Route 123 & $1969-71$ & 3.15 & .2 & .0 \\
\hline 12 & 01105830 & $\begin{array}{l}\text { First Herring Brook } \\
\text { near Scituate } \\
\text { Center, Mass. }\end{array}$ & Grove Street & $1969-71$ & 1.74 & $<.1$ & .0 \\
\hline 13 & 01105845 & $\begin{array}{l}\text { South River at } \\
\text { Marshfield, Mass. }\end{array}$ & Old Ocean Street & $1969-71$ & 7.59 & 2.0 & 1.5 \\
\hline 14 & 01105848 & $\begin{array}{l}\text { Furnace Brook near } \\
\text { Marshfield, Mass. }\end{array}$ & School Street & $1970-71$ & .94 & $<.1$ & .0 \\
\hline 15 & 01105856 & $\begin{array}{l}{ }^{2} \text { Jones River at } \\
\text { outlet of Silver } \\
\text { Lake near } \\
\text { Kingston, Mass. }\end{array}$ & $\begin{array}{l}\text { Silver Lake } \\
\text { outlet }\end{array}$ & 1965 & 4.09 & 一 & - \\
\hline 16 & 01105858 & $\begin{array}{l}\text { Pine Brook near } \\
\text { Kingston, Mass. }\end{array}$ & $\begin{array}{l}75 \text { feet below } \\
\text { State Route } 27\end{array}$ & $1958-60$ & ${ }^{5} 3.14$ & 一 & - \\
\hline 17 & 01105860 & $\begin{array}{l}\text { Jones River Brook } \\
\text { near Plympton, Mass. }\end{array}$ & State Route 106 & $\begin{array}{l}1965 \\
1969-71\end{array}$ & 3.57 & .9 & .6 \\
\hline 18 & 01105862 & $\begin{array}{l}{ }^{2} \text { Jones River near } \\
\text { Kingston, Mass. }\end{array}$ & Private road & 1965 & 10.6 & - & - \\
\hline
\end{tabular}


Table 5.--Summary of 7-day low-flow characteristics, drainage area, and period of record for low-flow partial-record stations and miscellaneous sites (Continued)

\begin{tabular}{|c|c|c|c|c|c|c|c|}
\hline \multirow[t]{2}{*}{$\begin{array}{l}\text { Number } \\
\text { in } \\
\text { figures } \\
2 \text { and } 3\end{array}$} & \multirow[t]{2}{*}{$\begin{array}{l}\text { Station } \\
\text { number }\end{array}$} & \multirow[t]{2}{*}{ Station name } & \multirow[t]{2}{*}{ Location } & \multirow[t]{2}{*}{$\begin{array}{l}\text { Period } \\
\text { of } \\
\text { record }\end{array}$} & \multirow[t]{2}{*}{$\begin{array}{l}\text { Drainage } \\
\text { area, } \\
\text { in } \\
\text { square } \\
\text { miles }\end{array}$} & \multirow{2}{*}{\multicolumn{2}{|c|}{$\begin{array}{c}\text { Estimated } \\
\text { annual minimum } \\
7 \text {-day mean } \\
\text { low flow, in } \\
\text { cubic feet per } \\
\text { second, at } \\
\text { indicated } \\
\text { recurrence } \\
\text { interval } \\
\text { 2-year } \overline{10} \text {-year }\end{array}$}} \\
\hline & & & & & & & \\
\hline \multicolumn{8}{|c|}{ COASTAL BASINS OF THE SOUTH SHORE (Continued) } \\
\hline 20 & 01105872 & $\begin{array}{l}\text { Halls Brook at } \\
\text { Kingston, Mass. }\end{array}$ & $\begin{array}{l}600 \text { feet above } \\
\text { State Route } 3 \mathrm{~A}\end{array}$ & $1969-71$ & 3.98 & 3.8 & 2.2 \\
\hline 21 & 01105874 & $\begin{array}{l}{ }^{6} \text { Town Brook at } \\
\text { Plymouth, Mass. }\end{array}$ & At mouth & $1969-71$ & 9.04 & 11 & 9.2 \\
\hline 22 & 01105876 & $\begin{array}{l}{ }^{1} \text { Eel River near } \\
\text { Plymouth, Mass. }\end{array}$ & State Route $3 \mathrm{~A}$ & $1969-70$ & 14.7 & 18 & 15 \\
\hline 23 & 01105878 & $\begin{array}{l}\text { Beaver Dam Brook } \\
\text { at White Horse } \\
\text { Beach, Mass. }\end{array}$ & $\begin{array}{l}800 \text { feet above } \\
\text { mouth }\end{array}$ & $1969-71$ & 5.52 & 6.2 & 4.6 \\
\hline 24 & 01105883 & $\begin{array}{l}\text { Herring River at } \\
\text { Bournedale, Mass. }\end{array}$ & At mouth & $1969-71$ & 7.74 & 3.8 & 2.3 \\
\hline \multicolumn{8}{|c|}{ COASTAL BASINS OF BUZZARDS BAY } \\
\hline 25 & 01105886 & $\begin{array}{l}{ }^{7} \text { Red Brook near } \\
\text { Buzzards Bay, Mass. }\end{array}$ & Red Brook Road & $1969-71$ & 9.84 & 3.8 & 1.8 \\
\hline 26 & 01105888 & $\begin{array}{l}\text { Agawam River near } \\
\text { Ellisville, Mass. }\end{array}$ & $\begin{array}{c}600 \text { feet below } \\
\text { Halfway Pond }\end{array}$ & $1969-71$ & 6.71 & 8.0 & 7.0 \\
\hline 27 & 01105890 & $\begin{array}{l}{ }^{7} \text { Agawam River at } \\
\text { East Wareham, Mass. }\end{array}$ & $\begin{array}{l}800 \text { feet below } \\
\text { Mill Pond }\end{array}$ & $1969-71$ & 17.1 & 25 & 20 \\
\hline 28 & 01105892 & $\begin{array}{l}{ }^{7} \text { Wankinco River } \\
\text { at Wareham, Mass. }\end{array}$ & $\begin{array}{l}1000 \text { feet below } \\
\text { Parker Mills Pond }\end{array}$ & $1969-71$ & 20.5 & 12 & 8.0 \\
\hline 29 & 01105895 & $\begin{array}{l}{ }^{18} \text { Weweantic } \\
\text { River at South } \\
\text { Wareham, Mass. }\end{array}$ & $\begin{array}{l}\text { Squire Island } \\
\text { Road }\end{array}$ & $1964-70$ & 56.1 & 15 & 10 \\
\hline 30 & 01105905 & $\begin{array}{l}\text { Sippican River near } \\
\text { Marion, Mass. }\end{array}$ & County Road & $1972-74$ & 28.1 & 5.0 & 3.5 \\
\hline 31 & 01105908 & $\begin{array}{l}\text { Aucoot Creek near } \\
\text { Marion, Mass. }\end{array}$ & U.S. Highway 6 & $1972-74$ & 2.71 & .1 & $<.1$ \\
\hline 32 & 011059101 & $\begin{array}{l}{ }^{4} \text { Mattapoisett } \\
\text { River at outlet } \\
\text { of Snipatuit Pond, } \\
\text { near Rochester, Mass. }\end{array}$ & $\begin{array}{l}\text { Snipatuit Pond } \\
\text { outlet }\end{array}$ & 1982 & - & - & - \\
\hline 33 & 011059105 & $\begin{array}{l}{ }^{4} \text { Mat tapoisett } \\
\text { River at Hartley Road, } \\
\text { near Rochester, Mass. }\end{array}$ & Hartley Road & 1982 & - & - & - \\
\hline 34 & 011059106 & $\begin{array}{l}\text { Mattapoisett River } \\
\text { tributary No. } 1 \text { near } \\
\text { Rochester, Mass. }\end{array}$ & Hartley Road & 1982 & 一 & - & - \\
\hline
\end{tabular}


Table 5.-Summary of 7-day low-flow characteristics, drainage area, and period of record for low-flow partial-record stations and miscellaneous sites (Continued)

\begin{tabular}{|c|c|c|c|c|c|c|}
\hline $\begin{array}{l}\text { Number } \\
\text { in } \\
\text { figures } \\
2 \text { and } 3\end{array}$ & $\begin{array}{l}\text { Station } \\
\text { number }\end{array}$ & Station name & Location & $\begin{array}{l}\text { Period } \\
\text { of } \\
\text { record }\end{array}$ & $\begin{array}{l}\text { Drainage } \\
\text { area, } \\
\text { in } \\
\text { square } \\
\text { miles }\end{array}$ & $\begin{array}{c}\text { Estimated } \\
\text { annual minimum } \\
7 \text {-day mean } \\
\text { low flow, in } \\
\text { cubic feet per } \\
\text { second, at } \\
\text { indicated } \\
\text { recurrence } \\
\text { interval } \\
\end{array}$ \\
\hline & & & & & & $\overline{2-y e a r} 10$-year \\
\hline
\end{tabular}

COASTAL BASINS OF BUZZARDS BAY (Continued)

\begin{tabular}{|c|c|c|c|c|c|c|c|}
\hline 35 & 011059107 & $\begin{array}{l}\text { Mattapoisett River } \\
\text { tributary No. } 2 \text { near } \\
\text { Rochester, Mass. }\end{array}$ & Cushman Road & 1982 & - & - & -- \\
\hline 36 & 01105911 & $\begin{array}{l}{ }^{49} \text { Mattapoisett } \\
\text { River near } \\
\text { Rochester, Mass. }\end{array}$ & $\begin{array}{l}\text { Rounseville } \\
\text { Road }\end{array}$ & $\begin{array}{l}1972-74 \\
1982\end{array}$ & 11.2 & 1.5 & 0.8 \\
\hline 37 & 011059115 & $\begin{array}{l}{ }^{4} \text { Mat tapoisett River } \\
\text { at New Bedford Road, } \\
\text { near Rochester, Mass. }\end{array}$ & $\begin{array}{l}\text { New Bedford } \\
\text { Road }\end{array}$ & 1982 & 13.1 & - & - \\
\hline 38 & 01105912 & $\begin{array}{l}{ }^{4} \text { Mat tapoisett River, } \\
\text { at old dam near } \\
\text { Rochester, Mass. }\end{array}$ & $\begin{array}{l}\text { Remains of old } \\
\text { dam }\end{array}$ & $\begin{array}{l}1965, \\
1982\end{array}$ & - & - & - \\
\hline 39 & 011059125 & $\begin{array}{l}\text { Mat tapoisett River } \\
\text { tributary No. } 3 \text { near } \\
\text { Rochester, Mass. }\end{array}$ & $\begin{array}{l}\text { Mattapoisett } \\
\text { Road }\end{array}$ & 1982 & - & - & - \\
\hline 40 & 01105913 & $\begin{array}{l}{ }^{4} \text { Mat tapoisett River } \\
\text { near Wolf Island Road, } \\
\text { near Rochester, Mass. }\end{array}$ & $\begin{array}{l}0.2 \text { mile below } \\
\text { Wolf Island } \mathrm{Rd} .\end{array}$ & 1982 & - & - & - \\
\hline 41 & 011059132 & $\begin{array}{l}\text { Branch Brook near } \\
\text { Mat tapoisett, Mass. }\end{array}$ & $\begin{array}{l}\text { Wolf Island } \\
\text { Road }\end{array}$ & 1982 & - & - & - \\
\hline 42 & 011059135 & $\begin{array}{l}\text { Crystal Spring near } \\
\text { Mat tapoisett, Mass. }\end{array}$ & $\begin{array}{l}30 \text { feet below } \\
\text { bridge on dirt } \\
\text { road (formerly } \\
\text { Tinkham Lane) }\end{array}$ & 1982 & - & - & - \\
\hline 43 & 01105914 & $\begin{array}{l}{ }^{49} \text { Mattapoisett } \\
\text { River near Matta- } \\
\text { poisett, Mass. }\end{array}$ & Tinkham Lane & $\begin{array}{l}1972-74 \\
1982\end{array}$ & 18.2 & 3.2 & 2.0 \\
\hline 44 & 01105915 & $\begin{array}{l}\text { Mat tapoisett River } \\
\text { tributary No.4, near } \\
\text { Mat tapoisett, Mass. }\end{array}$ & $\begin{array}{l}\text { Tinkham Pond } \\
\text { outlet }\end{array}$ & 1982 & - & - & - \\
\hline 45 & 01105916 & $\begin{array}{l}{ }^{4} \text { Mattapoisett River } \\
\text { near Acushnet Road, } \\
\text { near Mat tapoisett, } \\
\text { Mass. }\end{array}$ & $\begin{array}{l}\text { Footbridge } \\
\text { above Acushnet } \\
\text { Road }\end{array}$ & 1982 & 23.5 & - & - \\
\hline 46 & 01105917 & $\begin{array}{l}4910 \text { Mattapoisett } \\
\text { River near } \\
\text { Mat tapoisett, Mass. }\end{array}$ & $\begin{array}{c}0.4 \text { mile above } \\
\text { U.S. Route } 6\end{array}$ & $\begin{array}{l}1965 \\
1972-74, \\
1982\end{array}$ & 24.0 & 4.1 & 2.5 \\
\hline
\end{tabular}


Table 5.--Summary of 7-day low-flow characteristics, drainage area, and period of record for low-flow partial-record stations and miscellaneous sites (Continued).

\begin{tabular}{|c|c|c|c|c|c|c|c|}
\hline $\begin{array}{l}\text { Number } \\
\text { in } \\
\text { figures } \\
2 \text { and } 3\end{array}$ & $\begin{array}{l}\text { Station } \\
\text { number }\end{array}$ & Station name & Location & $\begin{array}{l}\text { Period } \\
\text { of } \\
\text { record }\end{array}$ & $\begin{array}{l}\text { Drainage } \\
\text { area, } \\
\text { in } \\
\text { square } \\
\text { miles }\end{array}$ & \multicolumn{2}{|c|}{$\begin{array}{l}\text { Estimated } \\
\text { annual minimum } \\
7 \text {-day mean } \\
\text { low flow, in } \\
\text { cubic feet per } \\
\text { second, at } \\
\text { indicated } \\
\text { recurrence } \\
\text { interval } \\
\text { 2-year 10-year }\end{array}$} \\
\hline \multicolumn{8}{|c|}{ COASTAL BASINS OF BUZZARDS BAY (Continued) } \\
\hline 47 & 01105920 & $\begin{array}{c}\text { Swift Brook at East } \\
\text { Fairhaven, Mass. }\end{array}$ & U.S. Route 6 & 1965 & 0.78 & - & -- \\
\hline 48 & 01105921 & $\begin{array}{l}\text { Swift Brook near } \\
\text { Mat tapoisett, Mass. }\end{array}$ & $\begin{array}{l}0.1 \text { mile above } \\
\text { Mattapoisett } \\
\text { Neck Road }\end{array}$ & $1972-73$ & 1.18 & 0.0 & 0.0 \\
\hline 49 & 01105924 & $\begin{array}{l}{ }^{11} \text { Acushnet River } \\
\text { at Leonard Street, } \\
\text { near Acushnet, Mass. }\end{array}$ & Leonard Street & $1972-74$ & 7.52 & .3 & .1 \\
\hline 50 & 01105926 & $\begin{array}{l}{ }^{11} \text { Acushnet River } \\
\text { at Acushnet, Mass. }\end{array}$ & Hamlin Road & $1972-74$ & 16.4 & .9 & .3 \\
\hline 51 & 01105928 & $\begin{array}{l}\text { Buttonwood Brook } \\
\text { near South } \\
\text { Dartmouth, Mass. }\end{array}$ & $\begin{array}{l}\text { Russells Mills } \\
\text { Road }\end{array}$ & $1972-74$ & 2.93 & $<.1$ & .0 \\
\hline 52 & 01105933 & $\begin{array}{l}{ }^{10} \text { Paskamanset River } \\
\text { near South } \\
\text { Dartmouth, Mass. }\end{array}$ & $\begin{array}{l}\text { Russells Mills } \\
\text { Road }\end{array}$ & $1972-74$ & 26.2 & 1.5 & .7 \\
\hline 53 & 01105935 & $\begin{array}{l}\text { Destruction Brook } \\
\text { near South } \\
\text { Dartmouth, Mass. }\end{array}$ & $\begin{array}{l}\text { Slades Corner } \\
\text { Road }\end{array}$ & $1972-74$ & 2.64 & .3 & .1 \\
\hline
\end{tabular}

${ }^{1}$ Recording gage, refer to table 2.

${ }^{2}$ Flow affected by diversion.

${ }^{3}$ Some regulation by ponds. Flow affected by diversion.

${ }^{4}$ Some regulation by pond or ponds.

${ }^{5}$ From Petersen, 1962.

${ }^{6}$ Diversion from Little South Pond for Plymouth water supply.

${ }^{7}$ Some regulation by operation of cranberry bogs.

${ }^{8}$ Flow regulated by ponds.

${ }^{9}$ Some unpublished daily records during $1959-60$ and 1981-82 are on file in the Massachusetts office.

${ }^{10}$ Streamflow affected by withdrawal of ground water.

${ }^{11}$ Diversion from New Bedford Reservoir. 


\section{SELECTED REFERENCES}

Benson, M. A., 1962, Factors influencing the occurrence of floods in a humid region of diverse terrain: U.S. Geological Survey Water-Supply Paper 1580-B, 64 p.

Brackley, R. A., and Wandle, S. W., Jr., 1983, Drainage divides, Massachusetts--Ipswich and lower Merrimack River basins and northeast coastal basins: U.S. Geological Survey Open-File Report 83-209, 28 maps.

Halliwell, D. B., Kimball, W. A., Screpetis, A. J., 1982, Massachusetts stream classification program, part I, Inventory of rivers and streams: Massachusetts Department of Environmental Quality Engineering and Department of Fisheries, Wildlife, and Recreational Vehicles, 126 p., appendix consisting of 3 pages.

Higgins, G. R., 1967, Yield of streams in Massachuset ts: Amherst, Massachusetts, University of Massachusetts, Water Resources Research Center Publication 5, 175 p.

Hutchison, N. E., compiler, 1975, WATSTORE-National water data storage and retrieval system of U.S. Geological Survey-User's guide: U.S. Geological Survey Open-File Report 75-426, 791 p. (revised).

Johnson, C. G., 1970, A proposed streamflow data program for central New England: U.S. Geological Survey open-file report, 38 p., 1 appendix consisting of 11 pages.

Johnson, C. G., and Tasker, G. D., 1974, Progress report on flood magnitude and frequency of Massachusetts streams: U.S. Geological Survey Open-File Report 74-131, 41 p.

Knox, C. E., and Nordenson, T. J., 1955, Average annual runoff and precipitation in the New England-New York area: U.S. Geological Survey Hydrologic Investigations Atlas 7, 6 p.

Knox, C. E., and Soule, R. M., 1949, Hydrology of Massachusetts, part 1, Summary of streamflow and precipitation records: U.S. Geological Survey Water-Supply Paper 1105, 240 p.

Langbein, W. B. and Iseri, K. T., 1960, General introduction and hydrologic definitions, in Manual of hydrology, part 1, General surface-water techniques: U.S. Geological Survey WaterSupply Paper 1541-A, p. 1-29.

Langbein, W. B., and others, 1947, Topographic characteristics of drainage basins: U.S. Geological Survey Water-Supply Paper 968-C, p. 125-157.

Lautzenheiser, R. E., 1969, Snowfall, snowfall frequencies, and snow cover data for New England: Environmental Sciences Services Administration Technical Memorandum EDSTM 12, $15 \mathrm{p}$.

Male, J. W., and Ogawa, H., 1982, Low flows of Massachusetts streams: Amherst, Massachusetts, University of Massachusetts, Water Resources Research Center Publication 125, 152 p.

Meeks, W. C., 1977, Daily values statistics (program A969), in Hutchison, N. E., compiler, 1975, WATSTORE--National water data storage and retrieval system of the U.S. Geological Survey user's guide: U.S. Geological Survey Open-File Report 75-426 (revised), chap. IV, section G.

Olimpio, J. C., and de Lima, Virginia, 1984, Ground-water resources of the Mattapoisett River Valley, Plymouth County, Massachusetts, aquifer: U.S. Geological Survey WaterResources Investigations Report 84-4043. 
Petersen, R. G., 1962, Records of selected wells, test holes, ponds, and streams in the BrocktonPembroke area, Massachusetts: U.S. Geological Survey open-file report, Massachusetts Basic-Data Report 5, ground-water series, 46 p.

Petersen, R. G., and Shaw, C. E., Jr., 1961, Ground-water favorability map of the Brockton-Pembroke area, Massachusetts: Massachusetts Water Resources Commission Hydrologic Investigations Chart HI-1.

Price, W. E., Jr., and Meeks, W. C., 1977, Daily values monthly and annual statistics (program W4422), in Hutchison, N. E., compiler, 1975, WATSTORE--National water data storage and retrieval system of the U.S. Geological Survey user's guide: U.S. Geological Survey Open-File Report 75-426 (revised), chap. IV, section F.

Riggs, H. C., 1971, Discussion of probability distribution of annual droughts by Eratakulan S. Joseph: American Society of Civil Engineers Proceedings, v. 97, no. IR3, p. 540-541.

1972, Low-flow investigations: U.S. Geological Survey Techniques of Water-Resources Investigations, book 4, chap. B1, 18 p.

Thomas, D. M., and Benson, M. A., 1970, Generalization of streamflow characteristics from drainage-basin characteristics: U.S. Geological Survey Water-Supply Paper 1975, 55 p.

U.S. Department of Agriculture, 1972, Soil Conservation Service National Engineering Handbook, section 4, Hydrology: U.S. Department of Agriculture, Soil Conservation Service.

U.S. Federal Inter-Agency River Basin Committee, Subcommittee on Hydrology, 1951, Interagency coordination of drainage area data, notes on hydrologic activities: Water Resources Council, Subcommittee on Hydrology Bulletin no. 4, 48 p.

U.S. Geological Survey, 1964, Compilation of records of surface waters in the United States, October 1950 to September 1960, part 1-A, North Atlantic Slope Basins, Maine to Connecticut: U.S. Geological Survey Water-Supply Paper 1721, 317 p.

1977, National handbook of recommended methods for water-data acquisition: U.S. Geological Survey, chap. 7, 38 p.

1980, Water resources data for Massachusetts and Rhode Island, water year 1979: U.S. Geological Survey Water-Data Report MA-RI-79-1, 349 p.

U.S. Weather Bureau, 1959a, Climates of the states, Massachusetts: U.S. Weather Bureau, Climatography of the United States, Paper No. 60-19, 20 p.

1959b, Rainfall intensity-frequency regime, northeastern United States: U.S. Weather Bureau Technical Paper no. 29, 35 p.

Wandle, S. W., Jr., 1982, Estimating peak discharges of small, rural streams in Massachusetts: U.S. Geological Survey Open-File Report 80-676, 33 p.

1983, Low-flow frequency and flow-duration analysis of natural-flow streams in Massachusetts: Boston Society of Civil Engineers Section, American Society of Civil Engineers Journal, v. 69, no. 1, p. 87-110.

$1984 a$, Gazet teer of hydrologic characteristics of streams in Massachusetts-coastal river basins of the North Shore and Massachusetts Bay: U.S. Geological Survey Water-Resources Investigations Report 84-4281. 
Wandle, S. W., Jr., 1984b, Gazet teer of hydrologic characteristics of streams in MassachusettsConnecticut River basin: U.S. Geological Survey Water-Resources Investigations Report 84-4282.

$1984 \mathrm{c}$, Gazet teer of hydrologic characteristics of streams in Massachusetts--Hudson River basin: U.S. Geological Survey Water-Resources Investigations Report 83-4250.

Wandle, S. W., Jr., and Fontaine, R. A., 1984, Gazetteer of hydrologic characteristics of streams in Massachusetts--Merrimack River basin: U.S. Geological Survey Water-Resources Investigations Report 84-4284.

Wandle, S. W., Jr., and Frimpter, M. H., 1982, Drainage divides, Massachusetts-Taunton River basin and southeast coastal basins: U.S. Geological Survey Open-File Report 82-870, 24 maps.

Wandle, S. W., Jr., and Keezer, G. R., 1984, Gazetteer of hydrologic characteristics of streams in Massachusetts-Taunton and Ten Mile River basins and coastal river basins of Mount Hope Bay, Narragansett Bay, and Rhode Island Sound: U.S. Geological Survey WaterResources Investigations Report 84-4283.

Wandle, S. W., Jr., and LeBlanc, J. A., 1984, Gazetteer of hydrologic characteristics of streams in Massachusetts-Thames River basin: U.S. Geological Survey Water-Resources Investigations Report 84-4287.

Wandle, S. W., Jr., and Lippert, R. G., 1984, Gazetteer of hydrologic characteristics of streams in Massachusetts--Housatonic River basin: U.S. Geological Survey Water-Resources Investigations Report 84-4285.

Wandle, S. W., Jr., and Phipps, A. F., 1984, Gazetteer of hydrologic characteristics of streams in Massachusetts--Blackstone River basin: U.S. Geological Survey Water-Resources Investigations Report 84-4286.

Williams, J. R., and Tasker G. D., 1974a, Water resources of the coastal drainage basins of southeastern Massachusetts, Weir River, Hingham, to Jones River, Kingston: U.S. Geological Survey Hydrologic Investigations Atlas HA-504.

$1974 \mathrm{~b}$, Water resources of the coastal drainage basins of southeastern Massachusetts, Plymouth to Weweantic River, Wareham: U.S. Geological Survey Hydrologic Investigations Atlas HA-507.

1978, Water resources of the coastal drainage basins of southeastern Massachusetts, northwest shore of Buzzards Bay: U.S. Geological Survey Hydrologic Investigations Atlas HA-560.

Williams, J. R., Tasker, G. D., and Willey, R. E., 1977, Hydrologic data of the coastal drainage basins of southeastern Massachusetts, Plymouth to Weweantic River, Wareham: U.S. Geological Survey open-file report 77-186, Massachusetts Hydrologic-Data Report No. 18, 31 p., 1 pl.

Williáms, J. R., Willey, R. E., and Tasker, G. D., 1975, Hydrologic data of the coastal drainage basins of southeastern Massachusetts, Weir River, Hingham, to Jones River, Kingston: U.S. Geological Survey open-file report, Massachusetts Hydrologic-Data Report No. 16, 63 p., 1 pl.

1980, Hydrologic data of the coastal drainage basins of southeastern Massachusetts, Northwest Shore of Buzzards Bay: U.S. Geological Survey Open-File Report 80-583, Massachusetts Hydrologic-Data Report No. 20, 30 p., 1 pl. 
- NOTES-

U. S. GOVERNMENT PRINTING OFFICE: $1985--501-448--20,011$ 